\title{
Loss of $\mathrm{P}_{2} \mathrm{Y}_{2}$ Nucleotide Receptors Enhances Early Pathology in the TgCRND8 Mouse Model of Alzheimer's Disease
}

\author{
Deepa Ajit ${ }^{1}$, Lucas T. Woods ${ }^{1}$, Jean M. Camden ${ }^{1}$, Christina N. Thebeau ${ }^{1}$, Farid G. El- \\ Sayed $^{1}$, W. Greeson Glen ${ }^{1}$, Laurie Erb ${ }^{1,4}$, Michael J. Petris ${ }^{1,2,4}$, Douglas C. Miller ${ }^{3}$, Grace Y. \\ Sun ${ }^{1,4}$, and Gary A. Weisman $1,4,{ }^{*}$ \\ ${ }^{1}$ Department of Biochemistry, University of Missouri, Columbia, Missouri, USA \\ ${ }^{2}$ Department of Nutritional Sciences and Exercise Physiology, University of Missouri, Columbia, \\ Missouri, USA \\ ${ }^{3}$ Department of Pathology and Anatomical Sciences, University of Missouri School of Medicine, \\ Columbia, Missouri, USA \\ ${ }^{4}$ Interdisciplinary Neurosciences Program, University of Missouri, Columbia, Missouri, USA
}

\section{Abstract}

\begin{abstract}
Neuroinflammation is a prominent feature in Alzheimer's disease (AD) and activation of the brain's innate immune system, particularly microglia, has been postulated to both retard and accelerate $\mathrm{AD}$ progression. Recent studies indicate that the $\mathrm{G}$ protein-coupled $\mathrm{P} 2 \mathrm{Y}_{2}$ nucleotide receptor $\left(\mathrm{P} 2 \mathrm{Y}_{2} \mathrm{R}\right)$ is an important regulator of innate immunity by assisting in the recruitment of monocytes to injured tissue, neutrophils to bacterial infections and eosinophils to allergen-infected lungs. In this study, we investigated the role of the $\mathrm{P} 2 \mathrm{Y}_{2} \mathrm{R}$ in progression of an AD-like phenotype in the TgCRND8 mouse model that expresses Swedish and Indiana mutations in amyloid precursor protein (APP). Our results indicate that $P 2 Y_{2} R$ expression is upregulated in TgCRND8 mouse brain within 10 weeks of age and then decreases after 25 weeks of age, as compared to littermate controls expressing low levels of the $P 2 Y_{2} R$. TgCRND8 mice with homozygous $P 2 Y_{2} R$ deletion survive less than 5 weeks, whereas mice with heterozygous $P 2 Y_{2} R$ deletion survive for 12 weeks, a time point when TgCRND8 mice are fully viable. Heterozygous $P 2 Y_{2} R$ deletion in TgCRND8 mice increased $\beta$-amyloid (A $\beta$ ) plaque load and soluble $A \beta_{1-42}$ levels in the cerebral cortex and hippocampus, decreased the expression of the microglial marker CD11b in these brain regions and caused neurological deficits within 10 weeks of age, as compared to age-matched TgCRND8 mice. These findings suggest that the $\mathrm{P} 2 \mathrm{Y}_{2} \mathrm{R}$ is important for the recruitment and activation of microglial cells in the TgCRND8 mouse brain and that the $\mathrm{P} 2 \mathrm{Y}_{2} \mathrm{R}$ may regulate neuroprotective mechanisms through microglia-mediated clearance of $A \beta$ that when lost can accelerate the onset of an AD-like phenotype in the TgCRND8 mouse.
\end{abstract}

\section{Introduction}

Neuroinflammation is manifested in Alzheimer's disease (AD), yet it remains unclear whether inflammation is a primary cause of disease progression or a protective response [1, 2]. During early stages of neuroinflammation, activated microglia secrete cytokines, chemokines and growth factors that induce neuroprotective responses [3, 4]. Previous studies have shown that modulation of inflammation in animal models of AD can affect

*Corresponding author: Gary A. Weisman, Department of Biochemistry, 540E Life Sciences Center, 1201 Rollins Road, University of Missouri, Columbia, MO, 65211-7310, USA., Phone: 573-882-5005, Fax: 573-884-2537, weismang@ missouri.edu.

Conflict of Interest: None 
disease progression [5-7]; however, clinical trials using anti-inflammatory drugs in AD have been inconclusive [2]. Therefore, unraveling the complex neuroinflammatory mechanisms associated with $\mathrm{AD}$ is necessary for development of novel $\mathrm{AD}$ therapies.

Extracellular nucleotides (e.g., ATP, ADP, UTP) are released from many cell types in response to both physiological and pathological stimuli, which activate a family of cellsurface nucleotide receptors consisting of 7 ligand-gated ion channels (i.e., P2XR1-7) and 8 G protein-coupled receptors (i.e., $\mathrm{P} \mathrm{YR}_{1}, 2,4,6,11-14$ ) $[8,9]$ to regulate a range of physiological responses [10-12], including neuroinflammation [13]. In particular, the $\mathrm{G}_{\mathrm{q}}$ protein-coupled $\mathrm{P}_{2} \mathrm{Y}_{2}$ receptor $\left(\mathrm{P}_{2} \mathrm{Y}_{2} \mathrm{R}\right)$ that is activated equipotently by ATP or UTP [14$16]$ has been identified as a modulator of neuroinflammatory processes, including those relevant to AD pathology [17-19]. Upregulation of $\mathrm{P} 2 \mathrm{Y}_{2} \mathrm{Rs}$ under inflammatory conditions occur in a variety of tissues and cells [20-23], including brain cells [24, 25], whereupon activation by ATP or UTP stimulates growth factor receptors, integrins and cytoskeletal proteins via unique structural motifs in the $\mathrm{P} 2 \mathrm{Y}_{2} \mathrm{R}$ that enable access to signaling pathways beyond the $\mathrm{G}_{\mathrm{q}}$ protein [26]. In rat primary cortical neurons, $\mathrm{P} 2 \mathrm{Y}_{2} \mathrm{Rs}$ are upregulated following treatment with interleukin-1 $\beta$ (IL-1 $\beta$ ) [24], a cytokine shown to be elevated in AD patients $[27,28]$. Subsequent $P 2 Y_{2} R$ activation stimulates non-amyloidogenic processing of amyloid precursor protein (APP) [24]. In mouse primary microglia, $A \beta_{1-42}$ treatment induces $\mathrm{P} 2 \mathrm{Y}_{2} \mathrm{R}$ upregulation that promotes microglial cell migration, and $\mathrm{A} \beta_{1-42}$ uptake and degradation [25]. $\mathrm{P} 2 \mathrm{Y}_{2} \mathrm{R}$ activation has been shown to inhibit trauma-induced death of astrocytic cells [29], suggesting that neuroprotective responses occur following activation of microglial, astrocytic and neuronal $\mathrm{P} 2 \mathrm{Y}_{2}$ Rs. Recent studies with post-mortem human AD brains have shown a decreased expression of $\mathrm{P}_{2} \mathrm{Y}_{2} \mathrm{Rs}$, as compared to non-AD controls [30]. However, the role of $\mathrm{P} 2 \mathrm{Y}_{2} \mathrm{R}$-mediated neuroprotection in $\mathrm{AD}$ remains unclear.

In this study, we assessed the effect of $P 2 Y_{2} R$ deletion in TgCRND8 mice, a well-studied AD mouse model that expresses the Swedish and Indiana mutant of APP (KM670/671NL $+\mathrm{V} 717 \mathrm{~F}$ ) [31]. We found that homozygous or heterozygous deletion of the $P 2 Y_{2} R$ significantly decreases longevity of the TgCRND8 mouse. Additionally, the heterozygous $P 2 Y_{2} R$ deletion was sufficient to significantly increase soluble $\mathrm{A} \beta_{1-42}$ levels and appearance of neurological deficits, as well as decrease the expression of the microglial cell marker $\mathrm{CD} 11 \mathrm{~b}$ in the brain, as compared to TgCRND8 mice with a full complement of the $P 2 Y_{2} R$. Taken together, our data suggest a neuroprotective function for the $\mathrm{P} 2 \mathrm{Y}_{2} \mathrm{R}$ in the TgCRND8 mouse that may represent a novel therapeutic target for the treatment of $\mathrm{AD}$, as well as other neurodegenerative diseases.

\section{Methods}

Reagents

TRIzol reagent, AlexaFluor 488 goat anti-rabbit IgG antibody, Texas Red goat anti-rat IgG antibody, Hoescht 33258 nuclear stain and the anti-human $A \beta_{1-42}$ sandwich ELISA kit were obtained from Life Technologies (Grand Island, NY). All other reagents were obtained from Sigma-Aldrich (St. Louis, MO) unless otherwise stated.

\section{Mice}

All animals were handled using protocols approved by the Institutional Animal Care and Use Committee (IACUC) of the University of Missouri (protocol \#6728). Heterozygous TgCRND8 mice $\left(\mathrm{Tg}^{+}\right)$, which express human APP containing the Swedish (K670N/M671L) and Indiana (V717F) mutations, were obtained from Dr. David Westaway (University of Toronto) [31] and were maintained on a mixed C3H/C57BL/6 strain background. Nontransgenic littermate $\left(\mathrm{Tg}^{-}\right)$mice on the mixed $\mathrm{C} 3 \mathrm{H} / \mathrm{C} 57 \mathrm{BL} / 6$ strain background that do not 
express human APP with Swedish and Indiana mutations were used as negative controls for experiments. $\mathrm{P}_{2} \mathrm{Y}_{2} \mathrm{R}^{-1-}$ mice (stock \#009132) were purchased from Jackson Laboratories (Bar Harbor, ME) and were maintained on a C57BL/6 strain background. TgCRND8 $\left(\mathrm{Tg}^{+}\right)$ mice were bred with $\mathrm{P} 2 \mathrm{Y}_{2} \mathrm{R}^{-/}$mice to generate TgCRND8 ${ }^{+} / \mathrm{P}_{2} \mathrm{Y}_{2} \mathrm{R}^{+/-}$heterozygotes $\left(\mathrm{Tg}^{+} \mathrm{P} 2 \mathrm{Y}_{2} \mathrm{R}^{+/-}\right)$and littermate $\mathrm{TgCRND} 8^{-} / \mathrm{P} 2 \mathrm{Y}_{2} \mathrm{R}^{+/-}\left(\mathrm{Tg}^{-} \mathrm{P} 2 \mathrm{Y}_{2} \mathrm{R}^{+/-}\right)$mice. Additionally, $\mathrm{Tg}^{+} \mathrm{P} 2 \mathrm{Y}_{2} \mathrm{R}^{+/-}$heterozygotes were bred with $\mathrm{P} 2 \mathrm{Y}_{2} \mathrm{R}^{-/-}$mice to generate $\mathrm{TgCRND}^{+} /$ $\mathrm{P} 2 \mathrm{Y}_{2} \mathrm{R}^{-l-}\left(\mathrm{Tg}^{+} \mathrm{P} 2 \mathrm{Y}_{2} \mathrm{R}^{-l-}\right)$ homozygous knockout mice. All mice were bred at the Christopher S. Bond Life Sciences Center Animal Facility of the University of Missouri, Columbia, MO. Animals were housed in vented cages with $12 \mathrm{~h}$ light/dark cycles and received food and water ad libitum. All mice were genotyped by PCR using appropriate primers, as described previously [31,32]. Age-matched male and female mice were utilized for all experiments.

\section{Quantitative real-time PCR}

For quantitative RT-PCR, whole brains from $\mathrm{Tg}^{+}, \mathrm{Tg}^{+} \mathrm{P} 2 \mathrm{Y}_{2} \mathrm{R}^{+/-}$and littermate control $\left(\mathrm{Tg}^{-}\right.$ or $\mathrm{Tg}^{-} \mathrm{P} 2 \mathrm{Y}_{2} \mathrm{R}^{+/-}$) mice were excised and the olfactory bulb and cerebellum were removed. The cortex and hippocampus from one hemisphere was then homogenized in TRIzol Reagent and incubated at room temperature for $5 \mathrm{~min}$. Chloroform $(0.2 \mathrm{ml} / \mathrm{ml} \mathrm{TRIzol})$ was added and the samples were incubated for $5 \mathrm{~min}$ at room temperature. Following centrifugation $\left(12,000 \times \mathrm{g}\right.$ for $15 \mathrm{~min}$ at $\left.4^{\circ} \mathrm{C}\right)$, total RNA was isolated from brain samples and purified using the RNeasy Plus Mini Kit (Qiagen, Valencia, CA). cDNA was synthesized from $500 \mathrm{ng}$ purified RNA using the Advantage RT for PCR Kit (Clontech Laboratories, Mountain View, CA). TaqMan probes for $P 2 Y_{2} R, C D 11 b$ and $18 S$ endogenous control were obtained from Applied Biosystems (Foster City, CA). The samples were prepared in quadruplicate and subjected to RT-PCR on an Applied Biosystems 7500 RealTime PCR machine. After computing the relative amounts of the target gene, the data were normalized to $18 S$ for each sample and analyzed using Applied Biosystems software.

\section{Immunohistochemistry and immunofluorescence microscopy}

Whole mouse brains were excised, placed in 4\% (v/v) paraformaldehyde in PBS for $24 \mathrm{~h}$ and sent to IDEXX RADIL (Columbia, MO) where brains were embedded in paraffin and 5 $\mu \mathrm{m}$ coronal sections were prepared from each of the frontal, parietal and occipital lobes and the cerebellum. Slides were then stained with Congo Red and subjected to brightfield and polarized light microscopy. For quantification of amyloid plaques, a blind study was conducted by IDEXX RADIL in which Congo Red stained slides from $\mathrm{Tg}^{+}$and $\mathrm{Tg}^{+} \mathrm{P} 2 \mathrm{Y}_{2} \mathrm{R}^{+/-}(\mathrm{n}=5)$ mouse brain were viewed under polarized light and amyloid plaques displaying apple-green birefringence were manually counted. Alternatively, mouse brains were excised, snap frozen in 2-methylbutane chilled in liquid nitrogen and stored at $-80^{\circ} \mathrm{C}$ for further use. Brains were then thawed to $-20^{\circ} \mathrm{C}$ and $10 \mu \mathrm{m}$ sections were cut using a Leica CM1900 cryostat. Sections were adhered to glass slides and fixed in $4 \%(\mathrm{v} / \mathrm{v})$ paraformaldehyde for $20 \mathrm{~min}$ at $4^{\circ} \mathrm{C}$ followed by three 5 min washes in PBS. Sections were then treated with $0.1 \%(\mathrm{v} / \mathrm{v})$ Triton X-100, washed three times in PBS and incubated for $2 \mathrm{~h}$ at room temperature in blocking buffer (5\% (v/v) goat serum and $0.3 \mathrm{M}$ glycine in PBS). Sections were incubated with rabbit anti- $\beta$-amyloid antibody (1:200 dilution in blocking buffer; Cell Signaling Technology) for $16 \mathrm{~h}$ at $4^{\circ} \mathrm{C}$. Following three 5 min washes in PBS, sections were incubated for $1 \mathrm{~h}$ at room temperature in blocking buffer containing AlexaFluor 488 goat anti-rabbit IgG antibody diluted 1:1000 in blocking buffer. Following three washes in PBS, sections were incubated for $5 \mathrm{~min}$ at room temperature in Hoechst 33258 nuclear stain diluted 1:5000 in PBS. Slides were washed three times in PBS, mounted and fluorescence was visualized using a Nikon TI-E inverted microscope equipped with appropriate filters. Measurement of plaque size was performed on anti- $\beta$-amyloid antibody- 
stained brain sections by outlining plaques using the area auto-detect tool in the NIS Elements software (Nikon).

\section{Quantification of $A \beta_{1-42}$ levels}

Whole brains from $\mathrm{Tg}^{+}, \mathrm{Tg}^{+} \mathrm{P} 2 \mathrm{Y}_{2} \mathrm{R}^{+/-}$and littermate control $\left(\mathrm{Tg}^{-}\right.$or $\mathrm{Tg}^{-} \mathrm{P} 2 \mathrm{Y}_{2} \mathrm{R}^{+/-}$) mice (n $=8$ ) were excised and the olfactory bulb and cerebellum were removed. The cortex and hippocampus from one hemisphere were then homogenized in reaction buffer BSAT-DPBS comprised of $5 \%(\mathrm{w} / \mathrm{v})$ bovine serum albumin, $0.03 \%(\mathrm{v} / \mathrm{v})$ Tween-20 and protease inhibitor cocktail (Sigma-Aldrich) in PBS according to the manufacturer's instructions. For measurement of total $\mathrm{A} \beta_{1-42}$ levels, one aliquot of brain homogenate was extracted with $5 \mathrm{M}$ guanidine- $\mathrm{HCl}$ in $50 \mathrm{mM}$ Tris- $\mathrm{HCl}$ at $\mathrm{pH} 8$ followed by sonication. For measurement of soluble $\mathrm{A} \beta_{1-42}$ levels, one aliquot of brain homogenate was extracted with $0.4 \%(\mathrm{v} / \mathrm{v})$ diethylamine in $100 \mathrm{mM} \mathrm{NaCl}$, as described [33]. Samples were then diluted 1:50 in cold reaction buffer and centrifuged at $16,000 \times \mathrm{g}$ for $20 \mathrm{~min}$ at $4^{\circ} \mathrm{C}$. Quantification of $\mathrm{A} \beta$ levels was performed using an anti-human $A \beta_{1-42}$ sandwich ELISA, according to the manufacturer's instructions. All assays were performed in triplicate.

\section{SDS-PAGE and Western blot analysis}

For measurement of protein levels, whole brains from $\mathrm{Tg}^{+}, \mathrm{Tg}^{+} \mathrm{P} 2 \mathrm{Y}_{2} \mathrm{R}^{+/-}$and littermate control $\left(\mathrm{Tg}^{-}\right.$or $\mathrm{Tg}^{-} \mathrm{P} 2 \mathrm{Y}_{2} \mathrm{R}^{+/-}$) mice were excised and the olfactory bulb and cerebellum were removed. The cortex and hippocampus from one hemisphere were then homogenized in TPER (Tissue Protein Extraction Reagent; Thermo Scientific, Rockford, IL). Samples were centrifuged at $10,000 \times \mathrm{g}$ for $5 \mathrm{~min}$ to pellet cellular debris and supernatants were collected. Samples were normalized for protein concentration using a NanoDrop 1000 spectrophotometer and combined 1:1 with $2 \mathrm{X}$ Laemmli buffer $(20 \mathrm{mM}$ sodium phosphate, $\mathrm{pH} 7.0,20 \%$ (v/v) glycerol, $4 \%(\mathrm{w} / \mathrm{v})$ SDS, $0.01 \%(\mathrm{w} / \mathrm{v})$ bromophenol blue and $100 \mathrm{mM}$ dithiothreitol). For measurement of soluble APPa (sAPPa) levels, 10\% (w/v) homogenates of brain samples were prepared in buffer $(250 \mathrm{mM}$ sucrose, $20 \mathrm{mM}$ Tris, $1 \mathrm{mM}$ EDTA, 1 mM EGTA and protease inhibitor cocktail, according to the manufacturer's instructions, $\mathrm{pH}$ 7.4) and extracted with an equal volume of $0.4 \%(\mathrm{v} / \mathrm{v})$ diethylamine in $100 \mathrm{mM} \mathrm{NaCl}$. Samples were then centrifuged at $100,000 \times \mathrm{g}$ for $1 \mathrm{~h}$ at $4^{\circ} \mathrm{C}$ and supernatants were collected, neutralized with 0.1 volume of $0.5 \mathrm{M}$ Tris ( $\mathrm{pH}$ 6.8) and combined 4:1 with 5X Laemmli buffer. Western blot analysis was performed, as previously described [24]. Briefly, samples were subjected to $7.5 \%(\mathrm{w} / \mathrm{v})$ SDS-PAGE and transferred to nitrocellulose membranes. Membranes were blocked for $1 \mathrm{~h}$ with $5 \%(\mathrm{w} / \mathrm{v})$ non-fat dry milk in Trisbuffered saline containing $0.1 \%(\mathrm{v} / \mathrm{v})$ Tween-20 (TBST) and incubated overnight at $4{ }^{\circ} \mathrm{C}$ with 1:1000 dilution in TBST of mouse anti-human APP antibody clone 6E10 (Covance, Princeton, NJ), mouse anti-human sAPPa antibody clone 2B3 (Immuno-Biological Laboratories, Minneapolis, MN), rabbit anti-mouse ADAM10 antibody (Santa Cruz Biotechnology, Santa Cruz, CA), rabbit anti-mouse ADAM17 antibody (Santa Cruz Biotechnology), rabbit anti-mouse BACE1 antibody (Cell Signaling Technology, Danvers, MA) or rabbit anti-mouse a-tubulin antibody (Cell Signaling Technology). Membranes were washed three times in TBST and incubated with horseradish peroxidase-conjugated goat anti-rabbit IgG antibody or goat anti-mouse IgG antibody (1:2000 dilution in TBST, Santa Cruz Biotechnology) at room temperature for $1 \mathrm{~h}$. Blots were washed three times in TBST and visualized using enhanced chemiluminescent reagent (Thermo Scientific) for $1 \mathrm{~min}$. Protein bands were detected on X-ray film and quantified using a computer-driven scanner and Quantity One software (Bio-Rad, Hercules, CA).

\section{Gait analysis}

Gait parameters were evaluated using the CatWalk 7.1 system from Noldus Information Technology (Leesburg, VA). The CatWalk system objectively measures various parameters 
of gait including stride length, swing speed, paw contact area and step sequence patterns, among others. All data analyses were performed with a pixel threshold value $\geq 25$ arbitrary units. $\mathrm{Tg}^{+}$and $\mathrm{Tg}^{+} \mathrm{P} 2 \mathrm{Y}_{2} \mathrm{R}^{+/-}$mice were subjected to 3 days of walkway training and testing was performed on day 4 when the animals completed three runs without hesitation.

\section{Statistical analysis}

Quantitative data are presented as the means \pm S.E.M. of results from three or more independent experiments. Statistical significance was defined as $P<0.05$ and was calculated by two-tailed t-test or ANOVA where indicated, using GraphPad Prism software. Statistical differences between Kaplan-Meier survival curves were determined by Mantel-Cox test where significance was defined as $P<0.05$.

\section{Results}

\section{$\mathrm{P}_{2} \mathrm{Y}_{2}$ receptor upregulation in the brain of TgCRND8 mice}

Previous studies have demonstrated upregulation of the $P 2 Y_{2} R$ under various inflammatory conditions $[20,22,23,34]$. Further studies from our lab indicate that IL- $1 \beta$ or $A \beta_{1-42}$ induces $\mathrm{P} 2 \mathrm{Y}_{2} \mathrm{R}$ upregulation in primary cortical neurons and microglia $[24,25]$. Since increased levels of IL- $1 \beta$ and $A \beta_{1-42}$ are observed in the brains of AD mouse models [31] and $A D$ patients [27], we investigated the expression levels of $P 2 Y_{2} R$ mRNA in the brains of TgCRND8 $\left(\mathrm{Tg}^{+}\right)$mice and their littermate controls not expressing the TgCRND8 gene $\left(\mathrm{Tg}^{-}\right)$mice at $8-48$ weeks of age by RT-PCR analysis. Results show that by 10 weeks of age, $\mathrm{P} 2 \mathrm{Y}_{2} \mathrm{R}$ mRNA is significantly upregulated in TgCRND8 mouse brain, as compared to $\mathrm{Tg}^{-}$littermate controls (Figure 1). Upregulation of the $P 2 Y_{2} R$ is sustained through 25 weeks of age, but decreases by 48 weeks of age (Figure 1). These data indicate that the $P 2 Y_{2} R$ is upregulated in the brains of the TgCRND8 mouse model of AD at times when neuroinflammation is manifested, but not at a time point that corresponds to advanced stage of AD pathology [35].

\section{$\mathrm{P}_{2} \mathrm{Y}_{2} \mathrm{R}$ knockout in TgCRND8 mice increases mortality}

To investigate the role of the $\mathrm{P} 2 \mathrm{Y}_{2} \mathrm{R}$ in an AD mouse model, TgCRND8 mice were crossed with $\mathrm{P} 2 \mathrm{Y}_{2} \mathrm{R}^{-1-}$ mice. Surprisingly, homo- or heterozygous knockout of the $P 2 \mathrm{Y}_{2} R$ significantly increases mortality in the TgCRND8 mice. As shown in Figure 2A, KaplanMeier survival curves were generated for each of the following genotypes: TgCRND8 ( $\mathrm{n}=$ 25; $\left.\mathrm{Tg}^{+}\right), \mathrm{Tg}^{+} \mathrm{P} 2 \mathrm{Y}_{2} \mathrm{R}^{+/-}(\mathrm{n}=25), \mathrm{Tg}^{+} \mathrm{P} 2 \mathrm{Y}_{2} \mathrm{R}^{-/-}(\mathrm{n}=6), \mathrm{P} \mathrm{Y}_{2} \mathrm{R}^{-/-}(\mathrm{n}=24)$ and TgCRND8 $\mathrm{x}$ $\mathrm{C} 57 \mathrm{BL} / 6(\mathrm{n}=27)$ mice. The longevity of $\mathrm{Tg}^{+} \mathrm{P} 2 \mathrm{Y}_{2} \mathrm{R}^{+/-}$mice was significantly decreased as compared to $\mathrm{Tg}^{+}$mice or $\mathrm{P} 2 \mathrm{Y}_{2} \mathrm{R}^{-/-}$mice $(P<0.001$ for each). The median survival age for $\mathrm{Tg}^{+} \mathrm{P} 2 \mathrm{Y}_{2} \mathrm{R}^{+/-}$mice was shortened to 70 days, whereas no deaths occurred in the TgCRND8 or $\mathrm{P} 2 \mathrm{Y}_{2} \mathrm{R}^{-/-}$mice within 90 days, with TgCRND8 mice surviving for more than 8 months. There were no deaths observed in $\mathrm{P}_{2} \mathrm{Y}_{2} \mathrm{R}$ heterozygote littermate controls not expressing the TgCRND8 gene, $\mathrm{Tg}^{-} \mathrm{P} 2 \mathrm{Y}_{2} \mathrm{R}^{+/-}$mice within the 90 days (not shown). When $\mathrm{F}_{1}$ $\mathrm{Tg}^{+} \mathrm{P} 2 \mathrm{Y}_{2} \mathrm{R}^{+/-}$mice were crossed with $\mathrm{P} 2 \mathrm{Y}_{2} \mathrm{R}^{-/}$mice to generate $\mathrm{Tg}^{+} \mathrm{P} 2 \mathrm{Y}_{2} \mathrm{R}^{-/-}$mice, longevity was further decreased to a median survival age of 25.5 days, significantly shorter than for $\mathrm{Tg}^{+} \mathrm{P} 2 \mathrm{Y}_{2} \mathrm{R}^{+/-}$mice $(P<0.001)$. TgCRND8 mice and $\mathrm{P} 2 \mathrm{Y}_{2} \mathrm{R}^{-/-}$mice have different strain backgrounds, i.e., $\mathrm{C} 3 \mathrm{H} \times \mathrm{C} 57 \mathrm{BL} / 6$ mixed and C57BL/6, respectively, and strain background has been shown to influence the survival of TgCRND8 mice [31]. However, the life span of TgCRND8 x C57BL/6 mice was not significantly different from TgCRND8 or $\mathrm{P}_{2} \mathrm{Y}_{2} \mathrm{R}^{-/-}$mice, ruling out a contribution of the mixed background to the accelerated mortality of $\mathrm{Tg}^{+} \mathrm{P} 2 \mathrm{Y}_{2} \mathrm{R}^{+/-}$and $\mathrm{Tg}^{+} \mathrm{P} 2 \mathrm{Y}_{2} \mathrm{R}^{-/-}$mice. Post-mortem analysis of 10 -week-old $\mathrm{Tg}^{+} \mathrm{P} 2 \mathrm{Y}_{2} \mathrm{R}^{+/-}$mice did not show any lesions in the major organs (i.e., brain, ileum/cecum/ large intestine, kidneys, liver, lung, salivary glands, spleen, stomach and thymus) and bacterial/viral serology data were negative for Mycoplasma pulmonis, ectromelia, epizootic 
diarrhea of infant mice virus (EDIM), lymphocytic choriomeningitis virus (LCMV), mouse hepatitis virus (MHV), mouse norovirus (MNV), mouse parvovirus (MPV), mouse minute virus (MMV), pneumonia virus of mice (PVM), reovirus type 3 (REO3), Sendai virus, and Theiler's murine encephalomyelitis virus (TMEV), suggesting that organ failure and infection were not causes of premature death. As anticipated, RT-PCR analysis demonstrated that the levels of $\mathrm{P} 2 \mathrm{Y}_{2} \mathrm{R}$ mRNA expression in the brains of $\mathrm{Tg}^{+} \mathrm{P}_{2} \mathrm{Y}_{2} \mathrm{R}^{+/-}$ mice were significantly decreased by $\sim 50 \%(P<0.01)$, as compared to $\mathrm{Tg}^{+}$mice (Figure $2 \mathrm{~B})$. Due to the severely shortened lifespan of $\mathrm{Tg}^{+} \mathrm{P}_{2} \mathrm{Y}_{2} \mathrm{R}^{-/-}$homozygous knockout mice ( 25 days), further investigation into the role of the $\mathrm{P}_{2} \mathrm{Y}_{2} \mathrm{R}$ in the TgCRND8 mouse model was performed utilizing 10-week-old male and female heterozygous knockout mice $\mathrm{Tg}^{+} \mathrm{P} 2 \mathrm{Y}_{2} \mathrm{R}^{+/-}, \mathrm{TgCRND} 8$ and non-transgenic littermate control $\left(\mathrm{Tg}^{-}\right)$mice.

\section{Heterozygous knockout of the $P 2 Y_{2} R$ in TgCRND8 mice increases $A \beta$ levels}

Previous characterization of the TgCRND8 mouse has described the initial appearance of $A \beta$ plaques within the brain at $\sim 3$ months of age [31]. To investigate $\mathrm{A} \beta$ plaque levels, 10 -weekold TgCRND8 and $\mathrm{Tg}^{+} \mathrm{P} 2 \mathrm{Y}_{2} \mathrm{R}^{+/-}$mouse brains were sectioned and stained with Congo Red (Figures 3A-D) and then subjected to bright field microscopy (Figures 3A-B) or polarized light microscopy where $A \beta$ plaques were identified by their apple-green birefringence (Figures 3C-D). Alternatively, frozen brain sections from 10-week-old TgCRND8 and $\mathrm{Tg}^{+} \mathrm{P} 2 \mathrm{Y}_{2} \mathrm{R}^{+/-}$mice were stained with an anti- $\beta$-amyloid antibody (Figures $3 \mathrm{E}-\mathrm{F}$ ) and plaques were visualized under fluorescence microscopy. Both methods of plaque visualization showed increased plaque load in $\mathrm{Tg}^{+} \mathrm{P} 2 \mathrm{Y}_{2} \mathrm{R}^{+/-}$mouse brain (Figures 3B, D, F), as compared to age-matched TgCRND8 mouse brain (Figures 3A, C, E). A significant increase in $\mathrm{A} \beta$ plaque load $(P<0.01)$ was observed in the occipital, parietal and frontal lobes of $\mathrm{Tg}^{+} \mathrm{P} 2 \mathrm{Y}_{2} \mathrm{R}^{+/-}$mouse brain, as compared to age-matched TgCRND8 mouse brain (Figure 3G). There was also a significant increase in plaque size $(P<0.01)$ for $\mathrm{Tg}^{+} \mathrm{P} 2 \mathrm{Y}_{2} \mathrm{R}^{+/-}$vs. TgCRND8 mouse brains (Figure $3 \mathrm{H}$ ).

Previous reports with TgCRND8 mice have shown that levels of soluble $A \beta_{1-42}$ gradually increase from 4 to 8 weeks of age with accelerated accumulation beyond 10 weeks of age [31]. Accordingly, we investigated the levels of soluble $A \beta_{1-42}$ in 10-week-old $\mathrm{Tg}^{+} \mathrm{P} 2 \mathrm{Y}_{2} \mathrm{R}^{+/-}$and TgCRND8 mouse brains using human $\mathrm{A} \beta_{1-42}$-specific ELISA. There were significant increases in levels of both soluble and total $\mathrm{A} \beta_{1-42}(P<0.05)$ in the brains of $\mathrm{Tg}^{+} \mathrm{P} 2 \mathrm{Y}_{2} \mathrm{R}^{+/-}$mice, as compared to age-matched TgCRND8 mice (Figure 4). Taken together, these data suggest that the $\mathrm{P} 2 \mathrm{Y}_{2} \mathrm{R}$ may play a role in the regulation of production or degradation of $A \beta$ in TgCRND8 mouse brain.

\section{Heterozygous knockout of the $\mathrm{P}_{2} \mathrm{Y}_{2} \mathrm{R}$ in TgCRND8 mice does not affect APP, ADAM10/17 and BACE1 expression}

The TgCRND8 mouse model displays $~ 5$-fold increased expression of the human APP protein bearing both the Swedish and Indiana mutations, as compared to expression of endogenous mouse APP [31]. To determine whether increased levels of $A \beta$ in $\mathrm{Tg}^{+} \mathrm{P} 2 \mathrm{Y}_{2} \mathrm{R}^{+/-}$ mouse brain correlate with altered expression of APP, levels of APP holoprotein and its degradation product non-neurotoxic sAPPa were measured in $\mathrm{Tg}^{+} \mathrm{P} 2 \mathrm{Y}_{2} \mathrm{R}^{+/-}, \mathrm{TgCRND} 8$ and non-transgenic littermate control $\mathrm{Tg}^{-}$mouse brains. Results show a substantial increase in the expression of APP and sAPPa in TgCRND8 mouse brain, as compared to $\mathrm{Tg}^{-}$controls, but APP and sAPPa expression levels were similar in $\mathrm{Tg}^{+} \mathrm{P} 2 \mathrm{Y}_{2} \mathrm{R}^{+/-}$and TgCRND8 mouse brains (Figure 5A).

Previously, we demonstrated that activation of $\mathrm{P}_{2} \mathrm{Y}_{2} \mathrm{Rs}$ stimulates a-secretase-dependent APP processing in neurons and astrocytoma cells, which generates non-neurotoxic sAPPa rather than neurotoxic $A \beta[24,36]$. One possible explanation for increased $A \beta$ levels in 
$\mathrm{Tg}^{+} \mathrm{P} 2 \mathrm{Y}_{2} \mathrm{R}^{+/-}$mice (Figures 3 and 4 ) could be decreased a-secretase activity. However, sAPPa expression was similar in the brains of TgCRND8 and $\mathrm{Tg}^{+} \mathrm{P} 2 \mathrm{Y}_{2} \mathrm{R}^{+/-}$mice (Figure 5A). We also found that the a-secretases ADAM10 and ADAM17 (also known as TACE), members of the ADAM family of matrix metalloproteinases known to be the primary asecretases responsible for processing of the APP holoprotein $[37,38]$ and the regulation of $\mathrm{A} \beta$ levels in the brain $[39,40]$, were expressed at similar levels in $\mathrm{Tg}^{+} \mathrm{P} 2 \mathrm{Y}_{2} \mathrm{R}^{+/-}$and TgCRND8 mouse brain (Figure 5B). In addition, BACE1, the primary $\beta$-secretase responsible for $A \beta$ generation [41, 42] whose levels are altered in $A D$ patients $[43,44]$, is expressed at similar levels in $\mathrm{Tg}^{+} \mathrm{P} 2 \mathrm{Y}_{2} \mathrm{R}^{+/-}$and TgCRND8 mouse brain (Figure 5B).

\section{Heterozygous knockout of the $\mathrm{P}_{2} \mathrm{Y}_{2} \mathrm{R}$ in TgCRND8 mouse brain leads to reduced expression of the microglial cell marker CD11b}

It is now widely accepted that microglia in the brain can regulate degenerative or protective mechanisms depending on the conditions [45]. Previous studies from our laboratory have demonstrated that $\mathrm{P} 2 \mathrm{Y}_{2} \mathrm{R}$ activation increases the migration of microglia and their uptake and degradation of $A \beta[25]$. Expression of the microglial cell marker CD11b has been shown to increase during microglial activation [46], which enhances phagocytic activity [47]. Brain homogenates from $\mathrm{TgCRND} 8, \mathrm{Tg}^{+} \mathrm{P} 2 \mathrm{Y}_{2} \mathrm{R}^{+/-}$and non-transgenic littermate $\left(\mathrm{Tg}^{-}\right)$controls were subjected to RT-PCR analysis using primers for the microglial cell marker $C D 11 b$. Results demonstrate a significant decrease in $C D 11 b$ expression $(P<0.05)$ in the brains of $\mathrm{Tg}^{+} \mathrm{P} 2 \mathrm{Y}_{2} \mathrm{R}^{+/-}$mice, as compared to TgCRND8 mice (Figure 6). Together with enhanced $A \beta$ accumulation seen in $\mathrm{Tg}^{+} \mathrm{P} 2 \mathrm{Y}_{2} \mathrm{R}^{+/-}$mice (Figures 3 and 4), these results suggest that inefficient activation and/or decreased recruitment of microglia in TgCRND8 mouse brain upon $\mathrm{P} 2 \mathrm{Y}_{2} \mathrm{R}$ knockout leads to decreased phagocytic clearance of neurotoxic $\mathrm{A} \beta$, which may play a role in the early mortality of $\mathrm{Tg}^{+} \mathrm{P} 2 \mathrm{Y}_{2} \mathrm{R}^{+/-}$mice.

\section{Heterozygous knockout of the $\mathrm{P}_{2} \mathrm{Y}_{2} \mathrm{R}$ in TgCRND8 mice leads to neurological deficits and impaired gait}

Mice harboring neurological deficits display an abnormal limb-clasping reflex in which the limbs are flexed inwards rather than extended [48]. TgCRND8 and $\mathrm{Tg}^{+} \mathrm{P} 2 \mathrm{Y}_{2} \mathrm{R}^{+/-}$mice were elevated by the tail and qualitatively observed for the presence of abnormal limb-clasping reflex. At 10 weeks of age, $\mathrm{Tg}^{+} \mathrm{P} 2 \mathrm{Y}_{2} \mathrm{R}^{+/-}$mice displayed abnormal limb-clasping reflexes, whereas this abnormality was absent in age-matched TgCRND8 mice (Figure 7A). A further assessment of neurological status can be achieved by analyzing gait, a commonly used indication of possible locomotor dysfunction in mouse models of neurodegeneration, including Parkinson's disease, Huntington's disease, stroke and traumatic brain injury [4951]. Gait analysis using a Noldus CatWalk system indicated that $\mathrm{Tg}^{+} \mathrm{P} 2 \mathrm{Y}_{2} \mathrm{R}^{+-}$as compared to age-matched TgCRND8 mice $(\mathrm{n}=7)$ exhibited a significant decrease $(P<0.05)$ in swing speed (speed of the paw while not in contact with the walkway) and stride length (distance between successive paw placements) (Figures 7B, C). Additionally, the regularity index, a measure of interpaw coordination defined as the number of normal step sequence patterns relative to the number of paw placements, was significantly decreased $(P<0.05)$ in $\mathrm{Tg}^{+} \mathrm{P} 2 \mathrm{Y}_{2} \mathrm{R}^{+/-}$as compared to TgCRND8 mice (Figure 7D). These results support the hypothesis that the $\mathrm{P} 2 \mathrm{Y}_{2} \mathrm{R}$ plays a neuroprotective function in the TgCRND8 mouse model of $\mathrm{AD}$.

\section{Discussion}

We present evidence that the $\mathrm{P} 2 \mathrm{Y}_{2} \mathrm{R}$ plays a neuroprotective role in the TgCRND8 mouse model of AD, since global heterozygous deletion of the $P 2 Y_{2} R$ increased soluble and total $A \beta_{1-42}$ levels and $A \beta$ plaque deposition, decreased expression of the microglial cell marker $\mathrm{CD} 11 \mathrm{~b}$, enhanced neurological deficits and accelerated mortality, as compared to TgCRND8 
mice expressing a full complement of the $P 2 Y_{2} R$. Another interesting observation is that after the initial upregulation of $\mathrm{P}_{2} \mathrm{Y}_{2} \mathrm{R}$ during the early stage disease pathology of TgCRND8 mice (10-25 weeks), the expression of $\mathrm{P}_{2} \mathrm{Y}_{2} \mathrm{R}$ decreases as the mice age and disease progresses (25-48 week). Furthermore, we found that increased $A \beta$ accumulation in the $\mathrm{Tg}^{+} \mathrm{P} 2 \mathrm{Y}_{2} \mathrm{R}^{+/-}$mouse does not correlate with changes in levels of APP or the APP processing enzymes ADAM10, ADAM17 or BACE1 and, therefore, it seems likely that decreased microglial cell activation and/or recruitment due to $P 2 Y_{2} R$ deletion is a major factor in the inefficient $\mathrm{A} \beta$ clearance and the neurological deficits and shortened lifespan of $\mathrm{Tg}^{+} \mathrm{P} 2 \mathrm{Y}_{2} \mathrm{R}^{+/-}$mice. These data support the hypothesis that $\mathrm{P} 2 \mathrm{Y}_{2} \mathrm{R}$ provides neuroprotection in the TgCRND8 mouse model of AD and suggest a novel target for the treatment of neurodegenerative diseases.

Previous work has demonstrated that the $\mathrm{P}_{2} \mathrm{Y}_{2} \mathrm{R}$ is upregulated in cell and animal models of vascular, salivary gland and intestinal inflammation [22, 52, 53]. Upregulation of the $\mathrm{P}_{2} \mathrm{Y}_{2} \mathrm{R}$ has been shown to occur through the activation of the transcription factor NF- $\kappa \mathrm{B}$ that is known to regulate inflammatory responses [53]. We found that the $\mathrm{P}_{2} \mathrm{Y}_{2} \mathrm{R}$ is upregulated in TgCRND8 mice within 10 weeks of age (Figure 1), a time point that correlates with the initial appearance of $\mathrm{A} \beta$ plaques ( 10-12 weeks) [31]. $\mathrm{P} 2 \mathrm{Y}_{2} \mathrm{R}$ expression levels remain elevated through 25 weeks of age, but return to levels similar to $\mathrm{Tg}^{-}$littermate controls by 48 weeks. These data suggest that $\mathrm{P} 2 \mathrm{Y}_{2} \mathrm{R}$-mediated neuroprotection is available early in disease progression, but is lost in the later stages of disease. Interestingly, studies have demonstrated decreased levels of $\mathrm{P}_{2} \mathrm{Y}_{2} \mathrm{R}$ expression in post-mortem parietal cortex samples from $\mathrm{AD}$ patients as compared to non-AD controls [30], suggesting that loss of $\mathrm{P} 2 \mathrm{Y}_{2} \mathrm{R}$ contributes to end-stage events in $\mathrm{AD}$. However, whether $\mathrm{P} 2 \mathrm{Y}_{2} \mathrm{R}$ expression is upregulated early in human $\mathrm{AD}$ to slow disease progression is not known. Since we have shown that $\mathrm{P} 2 \mathrm{Y}_{2} \mathrm{R}$ expression is upregulated in rat primary cortical neurons by IL- $1 \beta$ [24] and by $\mathrm{A} \beta$ exposure in mouse primary microglia [25], it seems likely that $\mathrm{P} 2 \mathrm{Y}_{2} \mathrm{R}$-mediated neuroprotection (e.g., microglia-dependent $\mathrm{A} \beta$ clearance) would be most pronounced with inflammation at early stages of AD-like disease progression in TgCRND8 mice. The formation of insoluble $A \beta$ plaques and the presence of Tau-immunopositive dystrophic neurites within plaques are characteristic of AD [52-54]. TgCRND8 mice also develop amyloid plaques with associated dystrophic neurites, however, these neuritic plaques have been shown to be Tau-immunonegative $[31,57,58]$. Increased levels of neurotoxic soluble $\mathrm{A} \beta_{1-42}$ accurately correlate with cognitive decline in $\mathrm{AD}$ patients $[59,60]$. Our results demonstrate that soluble $\mathrm{A} \beta_{1-42}$ levels are significantly increased with heterozygous $P 2 Y_{2} R$ deletion in the $\mathrm{Tg}^{+} \mathrm{P} 2 \mathrm{Y}_{2} \mathrm{R}^{+/-}$mouse (Figure 4), in addition to increased $\mathrm{A} \beta$ plaque accumulation (Figure 3), suggesting that the $\mathrm{P} 2 \mathrm{Y}_{2} \mathrm{R}$ in vivo can directly regulate the steadystate levels of neurotoxic forms of $A \beta$. Generation of the neurotoxic $A \beta_{1-42}$ peptide requires sequential processing of the APP holoprotein by $\beta$ - and $\gamma$-secretases, whereas $\alpha$-secretase activity is required to generate the non-amyloidogenic sAPPa fragment [42,61,62]. Studies have demonstrated that the a-secretases (i.e., ADAM10/17) compete with $\beta$-secretase (i.e., BACE1) for the processing of APP [63-65]. Therefore, modulating the activity of asecretases can affect the production of neurotoxic forms of $A \beta$ [39]. Previous in vitro studies in our lab indicate that $\mathrm{P} 2 \mathrm{Y}_{2} \mathrm{R}$ activation in IL-1 $\beta$-treated rat primary cortical neurons increases ADAM10/17-mediated APP processing by a PI3K-, PKC- and ERK1/2-dependent pathway [24] and by a $\mathrm{Ca}^{2+}$-dependent, but PKC-independent pathway in human astrocytoma cells [36]. The current study indicates that there are no differences in the levels of APP, sAPPa, and $\alpha$ - or $\beta$-secretases between TgCRND8 and $\mathrm{Tg}^{+} \mathrm{P}_{2} \mathrm{Y}_{2} \mathrm{R}^{+/-}$mice (Figure 5 ) and, therefore, a decrease in $\mathrm{P} 2 \mathrm{Y}_{2} \mathrm{R}$-dependent $\alpha$-secretase or an increase in $\beta$-secretase expression upon heterozygous $P 2 Y_{2} R$ deletion does not contribute to the elevated levels of neurotoxic, soluble $\mathrm{A} \beta_{1-42}$ in $\mathrm{Tg}^{+} \mathrm{P} 2 \mathrm{Y}_{2} \mathrm{R}^{+/-}$mice (Figure 4). 
Under neuroinflammatory conditions associated with $\mathrm{AD}$, resident microglia become activated, proliferate and migrate towards and surround $\mathrm{A} \beta$ plaques [66], and blood-derived macrophages infiltrate the brain $[67,68]$. These activated microglia are thought to play a neuroprotective role through the phagocytosis [25, 69] and degradation [70] of neurotoxic forms of $A \beta$. The importance of microglia in controlling $A \beta$ levels has been demonstrated in $\mathrm{AD}$ mouse models and $\mathrm{AD}$ patients where $\mathrm{A} \beta$ immunization has been shown to decrease plaque load and increase microglial cell accumulation [71-73]. In the current study, we show that increased soluble and total $A \beta$ levels and plaque deposition (Figures 3 and 4 ) are associated with a decrease in the expression of the microglial cell marker CD11b in the brains of $\mathrm{Tg}^{+} \mathrm{P} 2 \mathrm{Y}_{2} \mathrm{R}^{+/-}$mice, as compared to TgCRND8 mice (Figure 6). These results are consistent with the finding that increases in $\mathrm{A} \beta$ levels correlate with decreased $\mathrm{CD} 11 \mathrm{~b}^{+}$ microglial cells in the brains of Tg2576 mice upon knockout of the CCR2 chemokine receptor [74]. Interestingly, it has previously been shown that prolonged IL- $1 \beta$ expression in the hippocampus of the APPswe/PS1dE9 mouse model of AD leads to a reduction in amyloid lesions that was attributed to increased activation of microglial cells [75], consistent with a role for IL- $1 \beta$-mediated $\mathrm{P} 2 \mathrm{Y}_{2} \mathrm{R}$ upregulation in the TgCRND8 mouse model of AD.

An Arg-Gly-Asp (RGD) motif in the first extracellular loop of the $\mathrm{P} 2 \mathrm{Y}_{2} \mathrm{R}$ has been shown to promote receptor interaction with $\alpha_{\mathrm{v}} \beta_{3 / 5}$ integrins and the integrin-associated protein CD47 that mediate nucleotide-induced cytoskeletal rearrangements and cell migration by enabling the $P 2 Y_{2} R$ to access pools of $G_{0}$ and $G_{12}$ proteins associated with these integrins, thereby activating Rac1 and RhoA GTPases to regulate actin polymerization [76-78]. We recently reported that upregulation of $\mathrm{P} 2 \mathrm{Y}_{2} \mathrm{Rs}$ in mouse primary microglial cells treated with oligomeric $A \beta$ enhances $A \beta$ uptake and degradation [25], a neuroprotective mechanism that could slow disease progression in vivo. Furthermore, our data show that $\mathrm{P} 2 \mathrm{Y}_{2} \mathrm{R}$-mediated uptake of fibrillar $A \beta_{1-42}$ requires $\alpha_{v}$ integrin, Src and Rac activities [25], suggesting a direct role for $\mathrm{P} 2 \mathrm{Y}_{2} \mathrm{R} / \mathrm{a}_{\mathrm{v}} \beta_{3 / 5}$ integrin interactions in $\mathrm{A} \beta$ uptake by microglia. $\mathrm{A} \beta$ interacts with a multi-component cell surface receptor complex, including the B-class scavenger receptor CD36, the $\alpha_{6} \beta_{1}$ integrin and CD47, to stimulate the phagocytic activity of microglial cells [79-81]. Since the P2 $\mathrm{Y}_{2} \mathrm{R}$ and CD36 both interact with CD47 and its associated integrins, it is possible that the multi-protein complex that regulates the phagocytosis of $\mathrm{A} \beta$ by microglia includes the $\mathrm{P} 2 \mathrm{Y}_{2} \mathrm{R}$.

We observed an abnormal limb-clasping reflex in $\mathrm{Tg}^{+} \mathrm{P} 2 \mathrm{Y}_{2} \mathrm{R}^{+/-}$mice (Figure 7), which is a non-specific marker of neurological deficits that has been used to evaluate neurodegeneration in AD and Huntington's Disease [82, 83]. Additionally, locomotor dysfunction such as reduced swing speed and stride length have been used to diagnose CNS damage in traumatic brain injury and stroke [48, 49] and in AD patients [84]. The neurological deficits seen with heterozygous $P 2 Y_{2} R$ deletion in TgCRND8 mice (Figure 7) may be due to loss of an important regulatory mechanism involved in neurite extension, such as modulation of TrkA signaling and cofilin activity [85, 86]. Alternatively, neurological deficits seen in $\mathrm{Tg}^{+} \mathrm{P} 2 \mathrm{Y}_{2} \mathrm{R}^{+/-}$mice may be secondary to increased accumulation of neurotoxic $A \beta$ as a result of loss of $P 2 Y_{2} R$-dependent $A \beta$ clearance by microglia, since it has been shown that incomplete $A \beta$ clearance is associated with early neuropathogenesis in $\mathrm{AD}$ [87]. The decrease in CD11b expression in $\mathrm{Tg}^{+} \mathrm{P} 2 \mathrm{Y}_{2} \mathrm{R}^{+/-}$mice as compared to TgCRND8 mice could indicate a decrease in the number of microglia in the brain or inefficient microglial cell activation, as CD11b has been shown to be upregulated in activated microglia in the AD brain [46]. While further studies are needed to determine the cause of reduced CD11b expression, these results suggest an important role of the P2 $\mathrm{Y}_{2} \mathrm{R}$ in enhancing microglia-mediated $\mathrm{A} \beta$ clearance. Future studies will help ascertain the molecular mechanism involved in $\mathrm{P}_{2} \mathrm{Y}_{2} \mathrm{R}$ deletion-dependent neurological deficits and validate $\mathrm{P} 2 \mathrm{Y}_{2} \mathrm{R}$ as a target for therapeutic intervention in AD. 
The data presented in this study provide strong in vivo evidence in support of the hypothesis that $\mathrm{P} 2 \mathrm{Y}_{2} \mathrm{R}$ upregulation and subsequent activation in TgCRND8 mouse brain mediates neuroprotective responses. $\mathrm{P} 2 \mathrm{Y}_{2} \mathrm{R}$ activation in endothelial cells also has been shown to regulate monocytic cell diapedesis [22, 88], a process necessary for blood-derived macrophages to cross the blood-brain barrier. Studies using tissue-specific deletion of $\mathrm{P}_{2} \mathrm{Y}_{2} \mathrm{Rs}$ in microglia, neurons and endothelial cells may help elucidate the relevance of $\mathrm{P} 2 \mathrm{Y}_{2} \mathrm{Rs}$ in each of these cell types to neuroprotection conferred by the $\mathrm{P} 2 \mathrm{Y}_{2} \mathrm{R}$ in the TgCRND8 mouse model of AD.

\section{Acknowledgments}

This work was supported by NIH grant AG018357.

\section{References}

1. Rivest S. Regulation of innate immune responses in the brain. Nat Rev Immunol. 2009; 9:429-439. [PubMed: 19461673]

2. Wyss-Coray T, Rogers J. Inflammation in Alzheimer disease-a brief review of the basic science and clinical literature. Cold Spring Harb Perspect Med. 2012; 2:a006346. [PubMed: 22315714]

3. Glezer I, Simard AR, Rivest S. Neuroprotective role of the innate immune system by microglia. Neuroscience. 2007; 147:867-883. [PubMed: 17459594]

4. Griffiths M, Neal JW, Gasque P. Innate immunity and protective neuroinflammation: new emphasis on the role of neuroimmune regulatory proteins. Int Rev Neurobiol. 2007; 82:29-55. [PubMed: 17678954]

5. Rozemuller AJ, van Gool WA, Eikelenboom P. The neuroinflammatory response in plaques and amyloid angiopathy in Alzheimer's disease: therapeutic implications. Curr Drug Targets CNS Neurol Disord. 2005; 4:223-233. [PubMed: 15975026]

6. McGeer EG, Klegeris A, McGeer PL. Inflammation, the complement system and the diseases of aging. Neurobiol Aging. 2005; 26(Suppl 1):94-97. [PubMed: 16198446]

7. Klegeris A, McGeer EG, McGeer PL. Therapeutic approaches to inflammation in neurodegenerative disease. Curr Opin Neurol. 2007; 20:351-357. [PubMed: 17495632]

8. Weisman GA, Camden JM, Peterson TS, Ajit D, Woods LT, Erb L. P2 receptors for extracellular nucleotides in the central nervous system: role of $\mathrm{P} 2 \mathrm{X} 7$ and $\mathrm{P} 2 \mathrm{Y}_{2}$ receptor interactions in neuroinflammation. Mol Neurobiol. 2012; 46:96-113. [PubMed: 22467178]

9. Burnstock G. Purinergic signalling: Its unpopular beginning, its acceptance and its exciting future. Bioessays. 2012; 34:218-225. [PubMed: 22237698]

10. Burnstock G. Purine and pyrimidine receptors. Cell Mol Life Sci. 2007; 64:1471-1483. [PubMed: 17375261]

11. Bodin P, Burnstock G. Purinergic signalling: ATP release. Neurochem Res. 2001; 26:959-969. [PubMed: 11699948]

12. Butt AM. ATP: a ubiquitous gliotransmitter integrating neuron-glial networks. Semin Cell Dev Biol. 2011; 22:205-213. [PubMed: 21376829]

13. Ferrero ME. Purinoceptors in inflammation: potential as anti-inflammatory therapeutic targets. Front Biosci. 2012; 17:2172-2186.

14. Soltoff SP, Avraham H, Avraham S, Cantley LC. Activation of $\mathrm{P} 2 \mathrm{Y}_{2}$ receptors by UTP and ATP stimulates mitogen-activated kinase activity through a pathway that involves related adhesion focal tyrosine kinase and protein kinase C. J Biol Chem. 1998; 273:2653-2660. [PubMed: 9446569]

15. Lustig KD, Sportiello MG, Erb L, Weisman GA. A nucleotide receptor in vascular endothelial cells is specifically activated by the fully ionized forms of ATP and UTP. Biochem J. 1992; 284 (Pt 3):733-739. [PubMed: 1320376]

16. Erb L, Lustig KD, Sullivan DM, Turner JT, Weisman GA. Functional expression and photoaffinity labeling of a cloned $P_{2}$ U purinergic receptor. Proc Natl Acad Sci U S A. 1993; 90:10449-10453.

[PubMed: 8248130] 
17. Hussl S, Boehm S. Functions of neuronal P2Y receptors. Pflugers Arch. 2006; 452:538-551. [PubMed: 16691392]

18. Peterson TS, Camden JM, Wang Y, Seye CI, Wood WG, Sun GY, Erb L, Petris MJ, Weisman GA. $\mathrm{P}_{2} \mathrm{Y}_{2}$ nucleotide receptor-mediated responses in brain cells. Mol Neurobiol. 2010; 41:356-366. [PubMed: 20387013]

19. Weisman GA, Ajit D, Garrad R, Peterson TS, Woods LT, Thebeau C, Camden JM, Erb L. Neuroprotective roles of the $\mathrm{P}_{2} \mathrm{Y}_{2}$ receptor. Purinergic Signal. 2012; 8:559-578. [PubMed: 22528682]

20. Koshiba M, Apasov S, Sverdlov V, Chen P, Erb L, Turner JT, Weisman GA, Sitkovsky MV. Transient up-regulation of $\mathrm{P}_{2} \mathrm{Y}_{2}$ nucleotide receptor mRNA expression is an immediate early gene response in activated thymocytes. Proc Natl Acad Sci U S A. 1997; 94:831-836. [PubMed: 9023342]

21. Turner JT, Weisman GA, Landon LA, Park M, Camden JM. Salivary gland nucleotide receptors: evidence for functional expression of both P2X and P2Y subtypes. Eur J Morphol. 1998; 36(Suppl):170-175. [PubMed: 9825916]

22. Seye CI, Kong Q, Erb L, Garrad RC, Krugh B, Wang M, Turner JT, Sturek M, Gonzalez FA, Weisman GA. Functional $\mathrm{P} 2 \mathrm{Y}_{2}$ nucleotide receptors mediate uridine $5^{\prime}$-triphosphate-induced intimal hyperplasia in collared rabbit carotid arteries. Circulation. 2002; 106:2720-2726. [PubMed: 12438299]

23. Seye CI, Gadeau AP, Daret D, Dupuch F, Alzieu P, Capron L, Desgranges C. Overexpression of $\mathrm{P}_{2} \mathrm{Y}_{2}$ purinoceptor in intimal lesions of the rat aorta. Arterioscler Thromb Vasc Biol. 1997; 17:3602-3610. [PubMed: 9437211]

24. Kong Q, Peterson TS, Baker O, Stanley E, Camden J, Seye CI, Erb L, Simonyi A, Wood WG, Sun GY, Weisman GA. Interleukin-1 $\beta$ enhances nucleotide-induced and $\alpha$-secretase-dependent amyloid precursor protein processing in rat primary cortical neurons via up-regulation of the $\mathrm{P}_{2} \mathrm{Y}_{2}$ receptor. J Neurochem. 2009; 109:1300-1310. [PubMed: 19317852]

25. Kim HJ, Ajit D, Peterson TS, Wang Y, Camden JM, Gibson Wood W, Sun GY, Erb L, Petris M, Weisman GA. Nucleotides released from $A \beta_{1-42}$-treated microglial cells increase cell migration and $A \beta_{1-42}$ uptake through $\mathrm{P}_{2} \mathrm{Y}_{2}$ receptor activation. J Neurochem. 2012; 121:228-238. [PubMed: 22353164]

26. Erb L, Weisman GA. Coupling of P2Y receptors to G proteins and other signaling pathways. WIREs Membr Transp Signal. 2012; 1:789-803.

27. Lee YJ, Han SB, Nam SY, Oh KW, Hong JT. Inflammation and Alzheimer's disease. Arch Pharm Res. 2010; 33:1539-1556. [PubMed: 21052932]

28. Cacabelos R, Alvarez XA, Franco-Maside A, Fernandez-Novoa L, Caamano J. Serum tumor necrosis factor (TNF) in Alzheimer's disease and multi-infarct dementia. Methods Find Exp Clin Pharmacol. 1994; 16:29-35. [PubMed: 8164471]

29. Burgos M, Neary JT, Gonzalez FA. P2Y 2 nucleotide receptors inhibit trauma-induced death of astrocytic cells. J Neurochem. 2007; 103:1785-1800. [PubMed: 17868308]

30. Lai MK, Tan MG, Kirvell S, Hobbs C, Lee J, Esiri MM, Chen CP, Francis PT. Selective loss of $\mathrm{P}_{2} \mathrm{Y}_{2}$ nucleotide receptor immunoreactivity is associated with Alzheimer's disease neuropathology. J Neural Transm. 2008; 115:1165-1172. [PubMed: 18506388]

31. Chishti MA, Yang DS, Janus C, Phinney AL, Horne P, Pearson J, Strome R, Zuker N, Loukides J, French J, Turner S, Lozza G, Grilli M, Kunicki S, Morissette C, Paquette J, Gervais F, Bergeron C, Fraser PE, Carlson GA, George-Hyslop PS, Westaway D. Early-onset amyloid deposition and cognitive deficits in transgenic mice expressing a double mutant form of amyloid precursor protein 695. J Biol Chem. 2001; 276:21562-21570. [PubMed: 11279122]

32. Wang M, Kong Q, Gonzalez FA, Sun G, Erb L, Seye C, Weisman GA. P2Y 2 nucleotide receptor interaction with $a_{V}$ integrin mediates astrocyte migration. J Neurochem. 2005; 95:630-640. [PubMed: 16135088]

33. DaSilva K, Brown ME, Westaway D, McLaurin J. Immunization with amyloid-beta using GMCSF and IL-4 reduces amyloid burden and alters plaque morphology. Neurobiol Dis. 2006; 23:433-444. [PubMed: 16766202] 
34. Turner JT, Weisman GA, Camden JM. Upregulation of $\mathrm{P}_{2} \mathrm{Y}_{2}$ nucleotide receptors in rat salivary gland cells during short-term culture. Am J Physiol. 1997; 273:C1100-1107. [PubMed: 9316432]

35. Ma K, Mount HT, McLaurin J. Region-specific distribution of beta-amyloid peptide and cytokine expression in TgCRND8 mice. Neurosci Lett. 2011; 492:5-10. [PubMed: 21295112]

36. Camden JM, Schrader AM, Camden RE, Gonzalez FA, Erb L, Seye CI, Weisman GA. P2Y 2 nucleotide receptors enhance a-secretase-dependent amyloid precursor protein processing. J Biol Chem. 2005; 280:18696-18702. [PubMed: 15778502]

37. Slack BE, Ma LK, Seah CC. Constitutive shedding of the amyloid precursor protein ectodomain is up-regulated by tumour necrosis factor-alpha converting enzyme. Biochem J. 2001; 357:787-794. [PubMed: 11463349]

38. Jorissen E, Prox J, Bernreuther C, Weber S, Schwanbeck R, Serneels L, Snellinx A, Craessaerts K, Thathiah A, Tesseur I, Bartsch U, Weskamp G, Blobel CP, Glatzel M, De Strooper B, Saftig P. The disintegrin/metalloproteinase ADAM10 is essential for the establishment of the brain cortex. J Neurosci. 2010; 30:4833-4844. [PubMed: 20371803]

39. Caccamo A, Oddo S, Billings LM, Green KN, Martinez-Coria H, Fisher A, LaFerla FM. M1 receptors play a central role in modulating AD-like pathology in transgenic mice. Neuron. 2006; 49:671-682. [PubMed: 16504943]

40. Donmez G, Wang D, Cohen DE, Guarente L. SIRT1 suppresses $\beta$-amyloid production by activating the a-secretase gene ADAM10. Cell. 2010; 142:320-332. [PubMed: 20655472]

41. Vassar R, Bennett BD, Babu-Khan S, Kahn S, Mendiaz EA, Denis P, Teplow DB, Ross S, Amarante P, Loeloff R, Luo Y, Fisher S, Fuller J, Edenson S, Lile J, Jarosinski MA, Biere AL, Curran E, Burgess T, Louis JC, Collins F, Treanor J, Rogers G, Citron M. Beta-secretase cleavage of Alzheimer's amyloid precursor protein by the transmembrane aspartic protease BACE. Science. 1999; 286:735-741. [PubMed: 10531052]

42. Vassar R, Kovacs DM, Yan R, Wong PC. The beta-secretase enzyme BACE in health and Alzheimer's disease: regulation, cell biology, function, and therapeutic potential. J Neurosci. 2009; 29:12787-12794. [PubMed: 19828790]

43. Yang LB, Lindholm K, Yan R, Citron M, Xia W, Yang XL, Beach T, Sue L, Wong P, Price D, Li $\mathrm{R}$, Shen Y. Elevated beta-secretase expression and enzymatic activity detected in sporadic Alzheimer disease. Nat Med. 2003; 9:3-4. [PubMed: 12514700]

44. Li R, Lindholm K, Yang LB, Yue X, Citron M, Yan R, Beach T, Sue L, Sabbagh M, Cai H, Wong $\mathrm{P}$, Price D, Shen Y. Amyloid beta peptide load is correlated with increased beta-secretase activity in sporadic Alzheimer's disease patients. Proc Natl Acad Sci U S A. 2004; 101:3632-3637. [PubMed: 14978286]

45. Weitz TM, Town T. Microglia in Alzheimer's Disease: It's All About Context. Int J Alzheimers Dis. 2012; 2012:314185. [PubMed: 22779026]

46. Akiyama H, McGeer PL. Brain microglia constitutively express beta-2 integrins. Journal of neuroimmunology. 1990; 30:81-93. [PubMed: 1977769]

47. Le Cabec V, Carreno S, Moisand A, Bordier C, Maridonneau-Parini I. Complement receptor 3 (CD11b/CD18) mediates type I and type II phagocytosis during nonopsonic and opsonic phagocytosis, respectively. J Immunol. 2002; 169:2003-2009. [PubMed: 12165526]

48. Lalonde R, Strazielle C. Brain regions and genes affecting limb-clasping responses. Brain Res Rev. 2011; 67:252-259. [PubMed: 21356243]

49. Carter RJ, Lione LA, Humby T, Mangiarini L, Mahal A, Bates GP, Dunnett SB, Morton AJ. Characterization of progressive motor deficits in mice transgenic for the human Huntington's disease mutation. J Neurosci. 1999; 19:3248-3257. [PubMed: 10191337]

50. Hetze S, Romer C, Teufelhart C, Meisel A, Engel O. Gait analysis as a method for assessing neurological outcome in a mouse model of stroke. J Neurosci Methods. 2012; 206:7-14. [PubMed: 22343052]

51. Neumann M, Wang Y, Kim S, Hong SM, Jeng L, Bilgen M, Liu J. Assessing gait impairment following experimental traumatic brain injury in mice. J Neurosci Methods. 2009; 176:34-44. [PubMed: 18805438] 
52. Schrader AM, Camden JM, Weisman GA. P2Y 2 nucleotide receptor up-regulation in submandibular gland cells from the NOD.B10 mouse model of Sjogren's syndrome. Arch Oral Biol. 2005; 50:533-540. [PubMed: 15848146]

53. Degagne E, Grbic DM, Dupuis AA, Lavoie EG, Langlois C, Jain N, Weisman GA, Sevigny J, Gendron FP. P2 $\mathrm{Y}_{2}$ receptor transcription is increased by $\mathrm{NF}-\kappa \mathrm{B}$ and stimulates cyclooxygenase-2 expression and PGE2 released by intestinal epithelial cells. J Immunol. 2009; 183:4521-4529. [PubMed: 19734210]

54. Tharp WG, Lee YH, Greene SM, Vincellete E, Beach TG, Pratley RE. Measurement of altered AbetaPP isoform expression in frontal cortex of patients with Alzheimer's disease by absolute quantification real-time PCR. J Alzheimers Dis. 2012; 29:449-457. [PubMed: 22258516]

55. Schmidt ML, DiDario AG, Lee VM, Trojanowski JQ. An extensive network of PHF tau-rich dystrophic neurites permeates neocortex and nearly all neuritic and diffuse amyloid plaques in Alzheimer disease. FEBS Lett. 1994; 344:69-73. [PubMed: 8181568]

56. Selkoe DJ. The deposition of amyloid proteins in the aging mammalian brain: implications for Alzheimer's disease. Ann Med. 1989; 21:73-76. [PubMed: 2504258]

57. Woodhouse A, Vickers JC, Adlard PA, Dickson TC. Dystrophic neurites in TgCRND8 and Tg2576 mice mimic human pathological brain aging. Neurobiol Aging. 2009; 30:864-874. [PubMed: 17950493]

58. Cummings BJ, Su JH, Geddes JW, Van Nostrand WE, Wagner SL, Cunningham DD, Cotman CW. Aggregation of the amyloid precursor protein within degenerating neurons and dystrophic neurites in Alzheimer's disease. Neuroscience. 1992; 48:763-777. [PubMed: 1378573]

59. Lue LF, Kuo YM, Roher AE, Brachova L, Shen Y, Sue L, Beach T, Kurth JH, Rydel RE, Rogers J. Soluble amyloid beta peptide concentration as a predictor of synaptic change in Alzheimer's disease. Am J Pathol. 1999; 155:853-862. [PubMed: 10487842]

60. McLean CA, Cherny RA, Fraser FW, Fuller SJ, Smith MJ, Beyreuther K, Bush AI, Masters CL. Soluble pool of Abeta amyloid as a determinant of severity of neurodegeneration in Alzheimer's disease. Ann Neurol. 1999; 46:860-866. [PubMed: 10589538]

61. Sisodia SS. Beta-amyloid precursor protein cleavage by a membrane-bound protease. Proc Natl Acad Sci U S A. 1992; 89:6075-6079. [PubMed: 1631093]

62. Roberts SB, Ripellino JA, Ingalls KM, Robakis NK, Felsenstein KM. Non-amyloidogenic cleavage of the beta-amyloid precursor protein by an integral membrane metalloendopeptidase. J Biol Chem. 1994; 269:3111-3116. [PubMed: 8300647]

63. O'Brien RJ, Wong PC. Amyloid precursor protein processing and Alzheimer's disease. Annu Rev Neurosci. 2011; 34:185-204. [PubMed: 21456963]

64. Skovronsky DM, Moore DB, Milla ME, Doms RW, Lee VM. Protein kinase C-dependent alphasecretase competes with beta-secretase for cleavage of amyloid-beta precursor protein in the transgolgi network. J Biol Chem. 2000; 275:2568-2575. [PubMed: 10644715]

65. Lichtenthaler SF. Alpha-secretase cleavage of the amyloid precursor protein: proteolysis regulated by signaling pathways and protein trafficking. Current Alzheimer research. 2012; 9:165-177. [PubMed: 21605033]

66. Bolmont T, Haiss F, Eicke D, Radde R, Mathis CA, Klunk WE, Kohsaka S, Jucker M, Calhoun ME. Dynamics of the microglial/amyloid interaction indicate a role in plaque maintenance. $\mathrm{J}$ Neurosci. 2008; 28:4283-4292. [PubMed: 18417708]

67. Simard AR, Soulet D, Gowing G, Julien JP, Rivest S. Bone marrow-derived microglia play a critical role in restricting senile plaque formation in Alzheimer's disease. Neuron. 2006; 49:489502. [PubMed: 16476660]

68. Hao W, Liu Y, Liu S, Walter S, Grimm MO, Kiliaan AJ, Penke B, Hartmann T, Rube CE, Menger MD, Fassbender K. Myeloid differentiation factor 88-deficient bone marrow cells improve Alzheimer's disease-related symptoms and pathology. Brain. 2011; 134:278-292. [PubMed: 21115468]

69. Shie FS, Breyer RM, Montine TJ. Microglia lacking E Prostanoid Receptor subtype 2 have enhanced Abeta phagocytosis yet lack Abeta-activated neurotoxicity. Am J Pathol. 2005; 166:1163-1172. [PubMed: 15793296] 
70. Jiang Q, Lee CY, Mandrekar S, Wilkinson B, Cramer P, Zelcer N, Mann K, Lamb B, Willson TM, Collins JL, Richardson JC, Smith JD, Comery TA, Riddell D, Holtzman DM, Tontonoz P, Landreth GE. ApoE promotes the proteolytic degradation of Abeta. Neuron. 2008; 58:681-693. [PubMed: 18549781]

71. Nicoll JA, Wilkinson D, Holmes C, Steart P, Markham H, Weller RO. Neuropathology of human Alzheimer disease after immunization with amyloid-beta peptide: a case report. Nat Med. 2003; 9:448-452. [PubMed: 12640446]

72. Boche D, Denham N, Holmes C, Nicoll JA. Neuropathology after active Abeta42 immunotherapy: implications for Alzheimer's disease pathogenesis. Acta Neuropathol. 2010; 120:369-384. [PubMed: 20632020]

73. Schenk D, Barbour R, Dunn W, Gordon G, Grajeda H, Guido T, Hu K, Huang J, Johnson-Wood K, Khan K, Kholodenko D, Lee M, Liao Z, Lieberburg I, Motter R, Mutter L, Soriano F, Shopp G, Vasquez N, Vandevert C, Walker S, Wogulis M, Yednock T, Games D, Seubert P. Immunization with amyloid-beta attenuates Alzheimer-disease-like pathology in the PDAPP mouse. Nature. 1999; 400:173-177. [PubMed: 10408445]

74. El Khoury J, Toft M, Hickman SE, Means TK, Terada K, Geula C, Luster AD. Ccr2 deficiency impairs microglial accumulation and accelerates progression of Alzheimer-like disease. Nat Med. 2007; 13:432-438. [PubMed: 17351623]

75. Shaftel SS, Kyrkanides S, Olschowka JA, Miller JN, Johnson RE, O’Banion MK. Sustained hippocampal IL-1 beta overexpression mediates chronic neuroinflammation and ameliorates Alzheimer plaque pathology. J Clin Invest. 2007; 117:1595-1604. [PubMed: 17549256]

76. Erb L, Liu J, Ockerhausen J, Kong Q, Garrad RC, Griffin K, Neal C, Krugh B, Santiago-Perez LI, Gonzalez FA, Gresham HD, Turner JT, Weisman GA. An RGD sequence in the P2 $\mathrm{Y}_{2}$ receptor interacts with $\alpha_{V} \beta_{3}$ integrins and is required for $\mathrm{G}_{\mathrm{O}}$-mediated signal transduction. J Cell Biol. 2001; 153:491-501. [PubMed: 11331301]

77. Bagchi S, Liao Z, Gonzalez FA, Chorna NE, Seye CI, Weisman GA, Erb L. The P2 $\mathrm{Y}_{2}$ nucleotide receptor interacts with $\alpha_{V}$ integrins to activate $G_{O}$ and induce cell migration. J Biol Chem. 2005; 280:39050-39057. [PubMed: 16186116]

78. Liao Z, Seye CI, Weisman GA, Erb L. The P2Y 2 nucleotide receptor requires interaction with $a_{V}$ integrins to access and activate $\mathrm{G}_{12}$. J Cell Sci. 2007; 120:1654-1662. [PubMed: 17452627]

79. Knauer MF, Soreghan B, Burdick D, Kosmoski J, Glabe CG. Intracellular accumulation and resistance to degradation of the Alzheimer amyloid A4/beta protein. Proc Natl Acad Sci U S A. 1992; 89:7437-7441. [PubMed: 1502155]

80. Bamberger ME, Harris ME, McDonald DR, Husemann J, Landreth GE. A cell surface receptor complex for fibrillar beta-amyloid mediates microglial activation. J Neurosci. 2003; 23:26652674. [PubMed: 12684452]

81. Koenigsknecht J, Landreth G. Microglial phagocytosis of fibrillar beta-amyloid through a $\beta 1$ integrin-dependent mechanism. J Neurosci. 2004; 24:9838-9846. [PubMed: 15525768]

82. Mangiarini L, Sathasivam K, Seller M, Cozens B, Harper A, Hetherington C, Lawton M, Trottier Y, Lehrach H, Davies SW, Bates GP. Exon 1 of the HD gene with an expanded CAG repeat is sufficient to cause a progressive neurological phenotype in transgenic mice. Cell. 1996; 87:493506. [PubMed: 8898202]

83. Komatsu M, Waguri S, Chiba T, Murata S, Iwata J, Tanida I, Ueno T, Koike M, Uchiyama Y, Kominami E, Tanaka K. Loss of autophagy in the central nervous system causes neurodegeneration in mice. Nature. 2006; 441:880-884. [PubMed: 16625205]

84. Maquet D, Lekeu F, Warzee E, Gillain S, Wojtasik V, Salmon E, Petermans J, Croisier JL. Gait analysis in elderly adult patients with mild cognitive impairment and patients with mild Alzheimer's disease: simple versus dual task: a preliminary report. Clin Physiol Funct Imaging. 2010; 30:51-56. [PubMed: 19799614]

85. Arthur DB, Akassoglou K, Insel PA. $\mathrm{P} 2 \mathrm{Y}_{2}$ receptor activates nerve growth factor/TrkA signaling to enhance neuronal differentiation. Proc Natl Acad Sci U S A. 2005; 102:19138-19143. [PubMed: 16365320] 
86. Peterson TS, Thebeau CN, Ajit D, Camden JM, Woods LT, Wood WG, Petris MJ, Sun GY, Erb L, Weisman GA. Up-regulation and activation of the $\mathrm{P}_{2} \mathrm{Y}_{2}$ nucleotide receptor mediate neurite extension in IL-1 $\beta$-treated mouse primary cortical neurons. J Neurochem. 2013

87. Yang CN, Shiao YJ, Shie FS, Guo BS, Chen PH, Cho CY, Chen YJ, Huang FL, Tsay HJ. Mechanism mediating oligomeric Abeta clearance by naive primary microglia. Neurobiol Dis. 2011; 42:221-230. [PubMed: 21220023]

88. Kukulski F, Ben Yebdri F, Bahrami F, Fausther M, Tremblay A, Sevigny J. Endothelial P2Y 2 receptor regulates LPS-induced neutrophil transendothelial migration in vitro. Molecular immunology. 47:991-999. [PubMed: 20022380] 


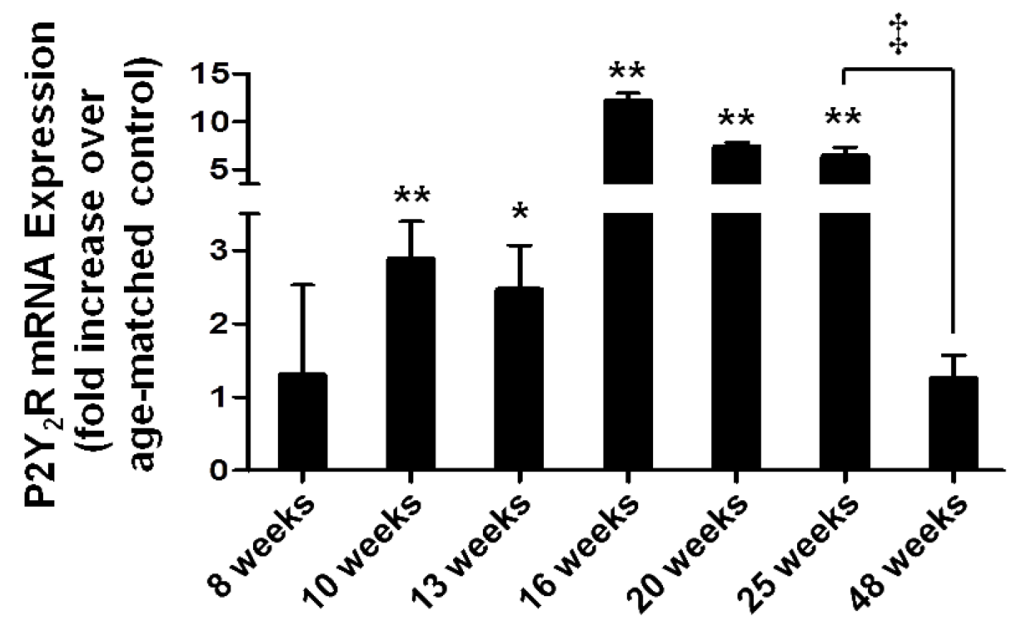

Figure 1. $\mathrm{P}_{2} \mathrm{Y}_{2} \mathrm{R}$ mRNA upregulation in the TgCRND8 mouse model

Brain samples from TgCRND8 $\left(\mathrm{Tg}^{+}\right)$and age-matched non-transgenic littermate control $\left(\mathrm{Tg}^{-}\right)$mice were harvested at the indicated time points and subjected to RT-PCR analysis using specific primers for the $\mathrm{P}_{2} \mathrm{Y}_{2} \mathrm{R}$, as described in Methods. Data are presented as means \pm S.E.M. $(n=4$ at 8,13 and 20 weeks, $n=6$ at 10 and 16 weeks and $n=3$ at 25 and 48 weeks) of the fold increase in $\mathrm{P} 2 \mathrm{Y}_{2} \mathrm{R}$ mRNA expression for $\mathrm{Tg}^{+}$over $\mathrm{Tg}^{-}$control mice, where $* P<0.05$ and $* * P<0.01$ indicate significant increases in $P 2 Y_{2} R$ expression over control, as determined by t-test, and $\ddagger P<0.05$ indicates a significant decrease in $\mathrm{P} 2 \mathrm{Y}_{2} \mathrm{R}$ expression at 48 weeks of age, as compared to 25 weeks of age, as determined by ANOVA. 
A

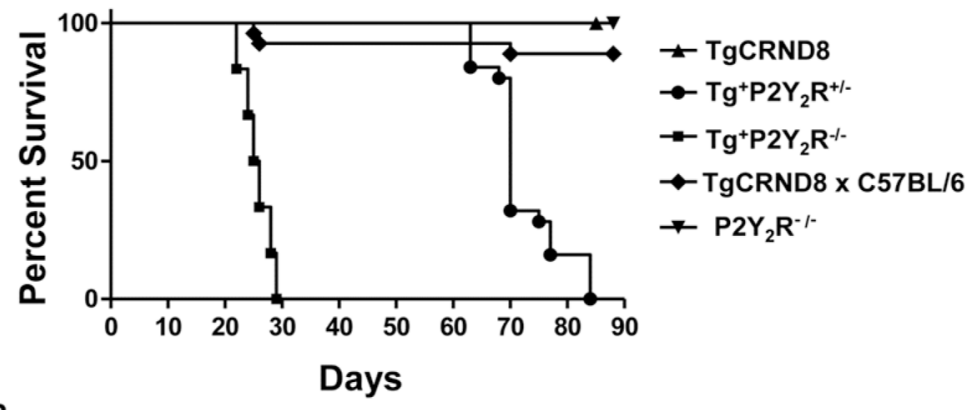

B

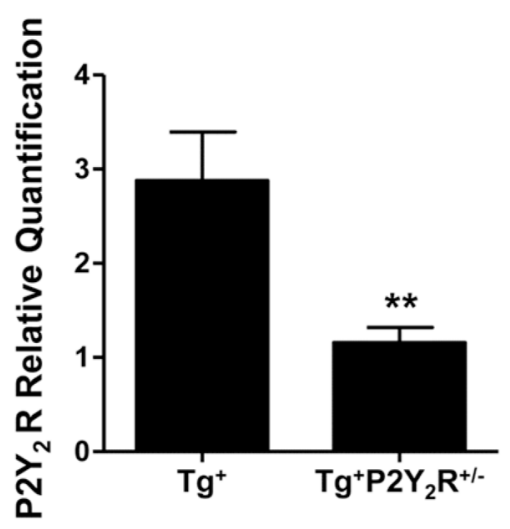

Figure 2. Homo- or heterozygous knockout of the $P 2 Y_{2} R$ in TgCRND8 mice increases mortality TgCRND8 $\left(\mathrm{Tg}^{+}\right)$mice were crossed with $\mathrm{P} 2 \mathrm{Y}_{2} \mathrm{R}^{-/-}$mice to generate $\mathrm{Tg}^{+} \mathrm{P} 2 \mathrm{Y}_{2} \mathrm{R}^{+/-}$and $\mathrm{Tg}^{+} \mathrm{P} 2 \mathrm{Y}_{2} \mathrm{R}^{-/-}$mice, as described in Methods. Additionally, TgCRND8 mice were crossed with C57BL/6 mice to investigate the effect of enrichment of the C57BL/6 background in $\mathrm{Tg}^{+}$mice. Mouse survival was monitored and Kaplan-Meier survival curves (A) were generated for TgCRND8 $(\mathrm{n}=25), \mathrm{Tg}^{+} \mathrm{P} 2 \mathrm{Y}_{2} \mathrm{R}^{+/-}(\mathrm{n}=25), \mathrm{Tg}^{+} \mathrm{P} 2 \mathrm{Y}_{2} \mathrm{R}^{-/-}(\mathrm{n}=6), \mathrm{P}_{2} \mathrm{Y}_{2} \mathrm{R}^{-/-}$ $(\mathrm{n}=24)$ and TgCRND8 $\times$ C57BL/6 $(\mathrm{n}=27)$ mice. The median survival ages of $\mathrm{Tg}^{+} \mathrm{P} 2 \mathrm{Y}_{2} \mathrm{R}^{+/-}$and $\mathrm{Tg}^{+} \mathrm{P} 2 \mathrm{Y}_{2} \mathrm{R}^{-/-}$mice were 70 and $25.5 \mathrm{~d}$, respectively, significantly less than TgCRND8, $\mathrm{P} 2 \mathrm{Y}_{2} \mathrm{R}^{-/-}$or TgCRND8 x C57BL/6 mice (Mantel-Cox test, $P<0.001$ for each). To compare $P 2 Y_{2} R$ expression in $\mathrm{Tg}^{+} \mathrm{P} 2 \mathrm{Y}_{2} \mathrm{R}^{+/-}$and $\mathrm{Tg}^{+}$mouse brains at 10 weeks of age, RNA was isolated from brain samples and cDNA was prepared for RT-PCR analysis (B), as described in Methods. Data are presented as means \pm S.E.M. $(n=6)$, where $* * P<$ 0.01 indicates a significant decrease in $\mathrm{P} 2 \mathrm{Y}_{2} \mathrm{R}$ mRNA expression, as compared to agematched TgCRND8 mice. 


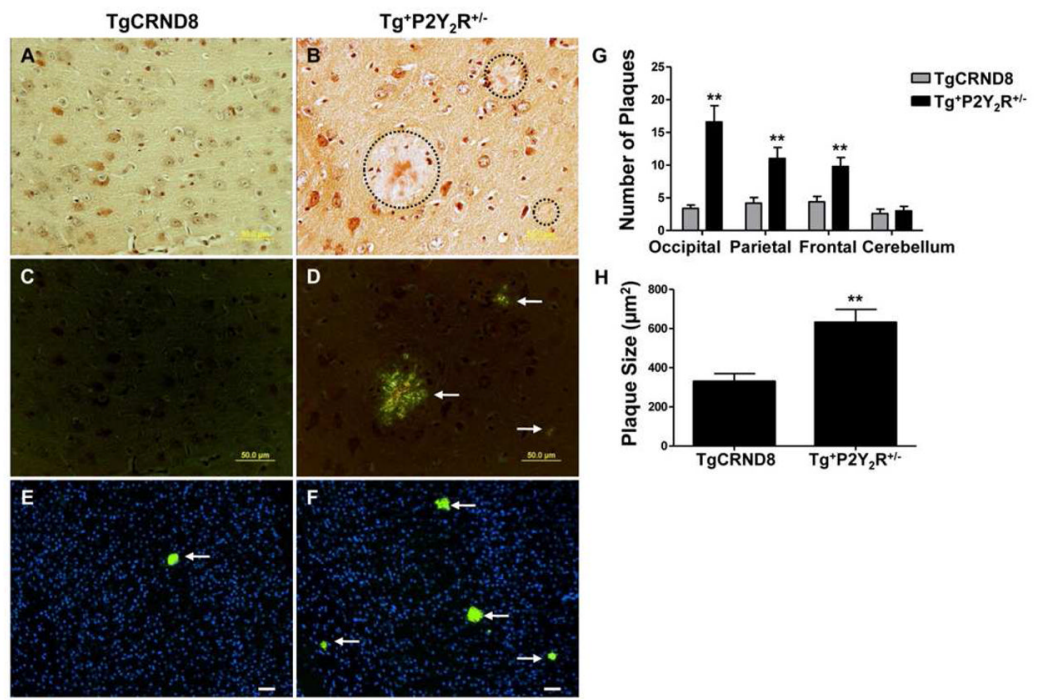

Figure 3. Heterozygous knockout of the $P 2 Y_{2} R$ increases $A \beta$ plaque load in the brains of $\mathrm{Tg}^{+} \mathbf{P} 2 \mathrm{Y}_{2} \mathrm{R}^{+/-}$mice

To investigate plaque load in 10-week-old TgCRND8 and $\mathrm{Tg}^{+} \mathrm{P} 2 \mathrm{Y}_{2} \mathrm{R}^{+/-}$mice, brain sections were prepared and stained with Congo Red (A-D) or A $\beta$-specific antibody (E-F), as described in Methods. Congo Red-stained cortical sections from TgCRND8 (A,C) or $\mathrm{Tg}^{+} \mathrm{P}_{2} \mathrm{Y}_{2} \mathrm{R}^{+/-}(\mathrm{B}, \mathrm{D})$ mouse brains were subjected to bright field microscopy (A-B) where plaques are encircled or polarized light microscopy $(\mathrm{C}-\mathrm{D})$ where plaques displaying applegreen birefringence are shown with arrows. Cortical sections from TgCRND8 (E) or $\mathrm{Tg}^{+} \mathrm{P}_{2} \mathrm{Y}_{2} \mathrm{R}^{+/-}(\mathrm{F})$ mouse brains were stained with an anti- $\mathrm{A} \beta$ antibody (green) and Hoescht nuclear stain (blue), where $\mathrm{A} \beta$ plaques are indicated with arrows. Micrographs are representative of results from at least 4 independent experiments and the scale bars $=50 \mu \mathrm{m}$. Using Congo Red-stained cortical sections, the number of plaques displaying apple-green birefringence was quantified $(\mathrm{G})$ and data are presented as means \pm S.E.M. $(\mathrm{n}=5)$, where ** $P<0.01$ indicates a significant increase in plaque number for $\mathrm{Tg}^{+} \mathrm{P}_{2} \mathrm{Y}_{2} \mathrm{R}^{+/-}$vs. agematched TgCRND8 mouse brain. Additionally, NIS Elements software was utilized to measure plaque size $(\mathrm{H})$ in brain sections stained with anti-A $\beta$ antibody. Data are presented as means \pm S.E.M. $(\mathrm{n}=6)$ of 40 plaques in TgCRND8 mice and 52 plaques in $\mathrm{Tg}^{+} \mathrm{P} 2 \mathrm{Y}_{2} \mathrm{R}^{+/-}$ mice, where ${ }^{*} P<0.01$ indicates a significant increase in plaque size for $\mathrm{Tg}^{+} \mathrm{P} 2 \mathrm{Y}_{2} \mathrm{R}^{+/-}$vs. TgCRND8 mouse brain. 


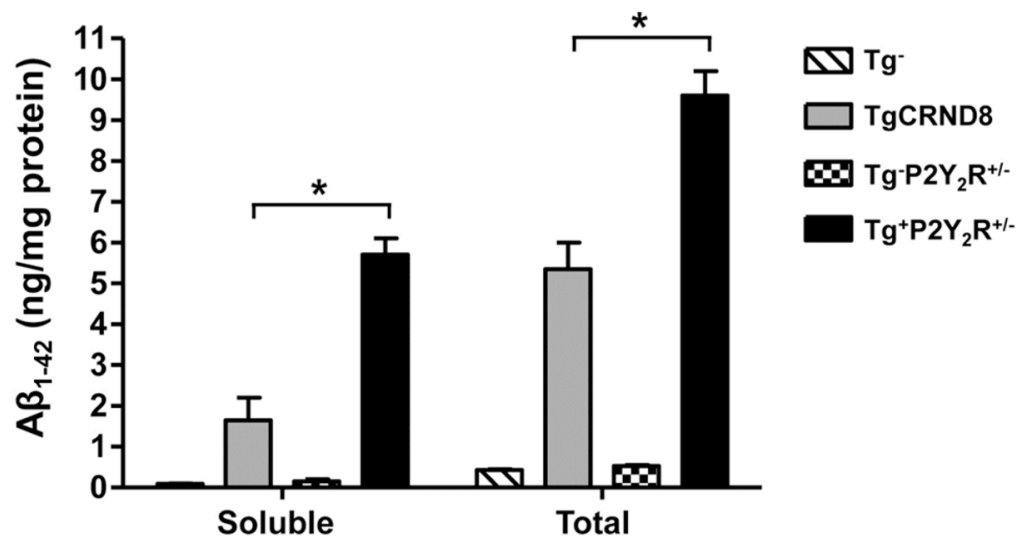

Figure 4. Heterozygous knockout of the $P 2 Y_{2} R$ increases soluble and total $A \beta_{1-42}$ levels in the brains of $\mathrm{Tg}^{+} \mathbf{P} 2 \mathrm{Y}_{2} \mathbf{R}^{+/-}$mice

For quantification of $A \beta_{1-42}$ levels, cortical brain samples from 10-week-old TgCRND8, $\mathrm{Tg}^{+} \mathrm{P} 2 \mathrm{Y}_{2} \mathrm{R}^{+/-}$and $\mathrm{Tg}^{-} \mathrm{P} 2 \mathrm{Y}_{2} \mathrm{R}^{+/-}$and non-transgenic littermate control $\left(\mathrm{Tg}^{-}\right)$mice were analyzed using a human anti-A $\beta_{1-42}$-specific ELISA, as described in Methods. Soluble $\mathrm{A} \beta_{1-42}$ and total $A \beta_{1-42}$ were isolated by extracting brain homogenates in $0.4 \%(\mathrm{v} / \mathrm{v})$ diethylamine or $5 \mathrm{M}$ guanidine- $\mathrm{HCl}$, respectively. As compared to TgCRND8 mice, brain samples from $\mathrm{Tg}^{+} \mathrm{P} 2 \mathrm{Y}_{2} \mathrm{R}^{+/-}$mice showed significant increases in both soluble and total $\mathrm{A} \beta_{1-42}$ levels. Data are presented as means \pm S.E.M. $(\mathrm{n}=8)$, where $* P<0.05$ indicates a significant difference, as compared to age-matched TgCRND8 mice. 
A

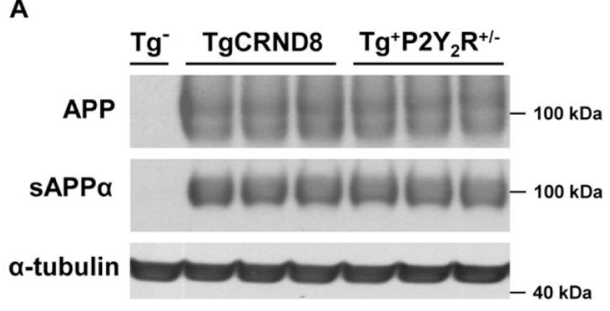

B

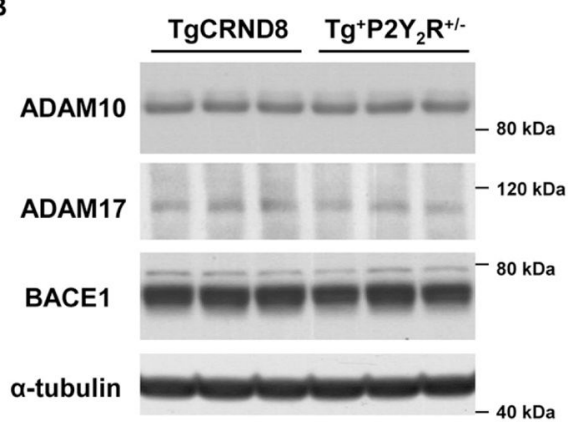

Figure 5. Heterozygous knockout of the $P_{2} Y_{2} R$ in TgCRND8 mice does not affect APP, sAPPa, ADAM10, ADAM17 and BACE1 expression

To evaluate expression levels of enzymes that regulate $A \beta_{1-42}$ levels, brain homogenates from 10-week-old TgCRND8, $\mathrm{Tg}^{+} \mathrm{P} 2 \mathrm{Y}_{2} \mathrm{R}^{+/-}$and non-transgenic littermate control $\left(\mathrm{Tg}^{-}\right)$ mice were subjected to Western analysis, as described in Methods. (A) APP and sAPPa levels were determined using anti-APP antibody (clone 6E10) and anti-sAPPa antibody (clone 2B3), respectively. (B) ADAM10, ADAM17 and BACE1 levels were determined using anti-ADAM10, anti-ADAM17 and anti-BACE1 antibodies, respectively. Blots are representative of results from $n=6$ mice for each genotype and a-tubulin was used as a loading control. 


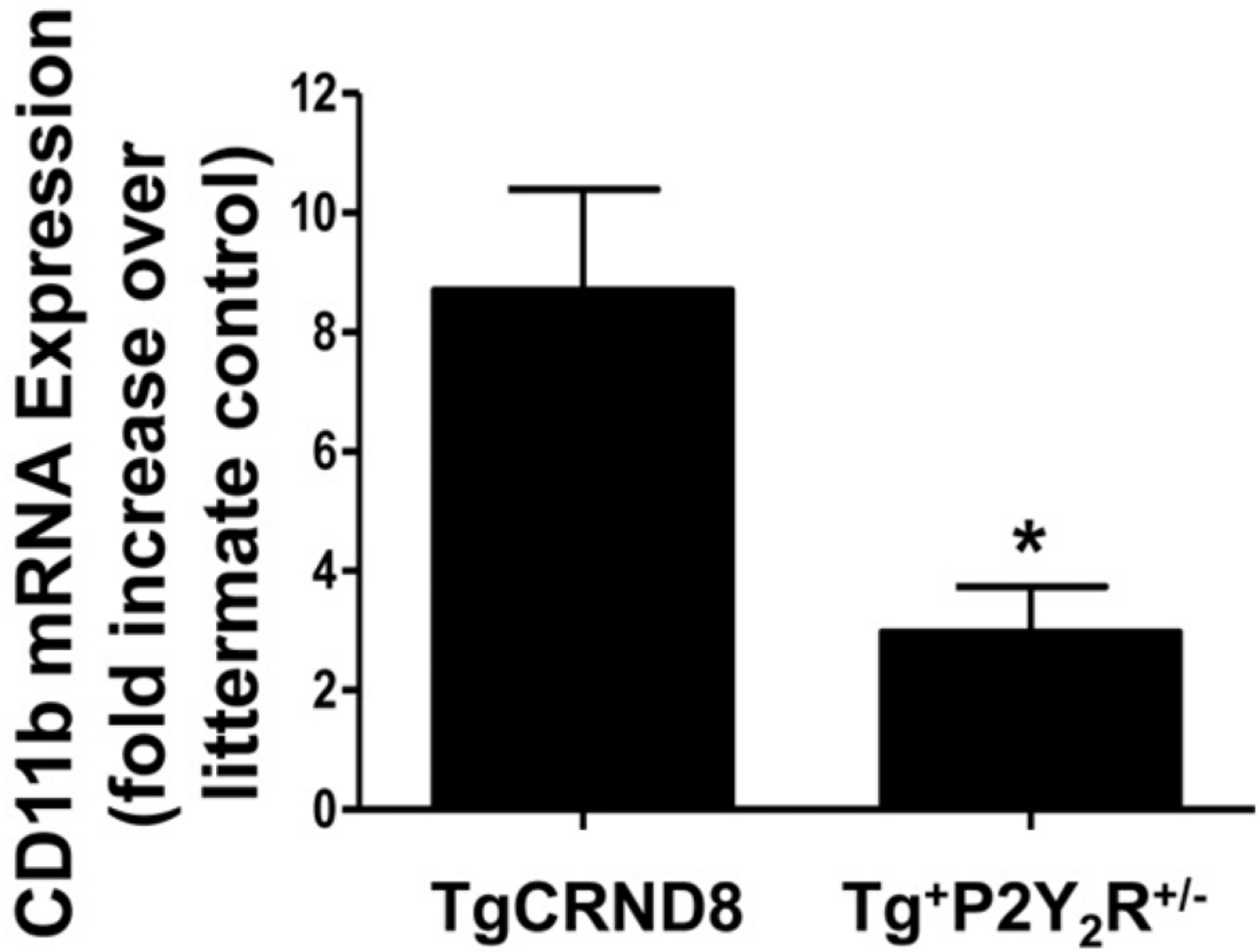

Figure 6. Heterozygous knockout of the $P 2 Y_{2} R$ in TgCRND8 mice leads to decreased expression of CD11b in the brain

Brain cell homogenates prepared from 10 -week-old TgCRND8 and $\mathrm{Tg}^{+} \mathrm{P} 2 \mathrm{Y}_{2} \mathrm{R}^{+/-}$mice, and $\mathrm{Tg}^{-} \mathrm{P} 2 \mathrm{Y}_{2} \mathrm{R}^{+/-}$and $\mathrm{Tg}^{-}$control mice $(\mathrm{n}=6)$ were subjected to RT-PCR analysis using specific primers for the microglial cell marker $C D 11 \mathrm{~b}$. The fold increase in CD11b mRNA expression over age-matched controls is expressed as the mean \pm S.E.M. $(n=6)$, where $* P<$ 0.05 indicates a significant decrease in CD11b mRNA expression, as compared to TgCRND8 mice. 


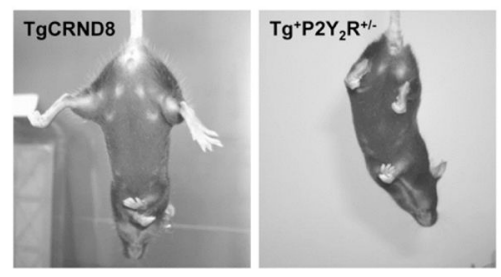

C

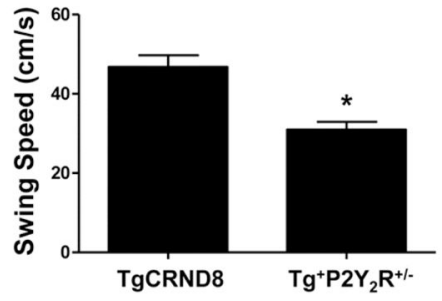

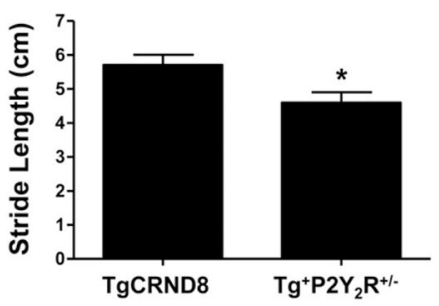

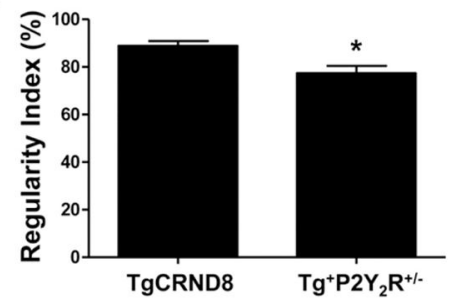

Figure 7. Heterozygous knockout of the $P 2 Y_{2} R$ in TgCRND8 mice leads to neurological deficits and locomotor dysfunction

General assessment of neurological function was performed using the tail hang test and gait analysis. (A) 10 -week-old $\mathrm{Tg}^{+} \mathrm{P} 2 \mathrm{Y}_{2} \mathrm{R}^{+/-}$mice display an abnormal limb-clasping reflex when suspended by the tail, whereas TgCRND8 mice display a normal reflex of hind limb extension. (B-D) Gait analysis was evaluated, as described in Methods. $\mathrm{Tg}^{+} \mathrm{P} 2 \mathrm{Y}_{2} \mathrm{R}^{+/-}$mice display significant locomotor dysfunction with decreases in (B) stride length, (C) swing speed and (D) regularity index. Data are expressed as means \pm S.E.M. $(n=7)$, where $* P<$ 0.05 indicates a significant decrease as compared to age-matched TgCRND8 mice. 